\title{
IZBORI I IMENOVANJA BISKUPÂ U \\ HERCEGOVINI U DOBA AUSTRO-UGARSKE VLADAVINE (1878.-1918.) NA PRIMJERU BISKUPA PAŠKALA BUCONJIĆA*
}

\author{
Petar VRANKIĆ \\ Kath.Theologische Fakultät der \\ Universität Augsburg \\ Privatadresse: \\ Kardinal-Brandmüller-Platz 1 \\ D - 82269 Geltendorf \\ E-pošta: vrankic@t-online.de
}

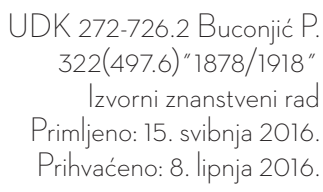

\section{Sažetak}

Izbor i imenovanje biskupâ u Katoličkoj crkvi bio je od pamtivijeka veoma kompleksan i crkveno-politički veoma osjetljiv predmet. Zaposjedanjem $\mathrm{BiH}$ 1878. godine te uvođenjem nove pravne, gospodarske i administrativne uprave, AustroUgarska je stvorila i nove odnose između države i vjerskih zajednica na području BiH. Poslije dvogodišnjih pregovora između Beča i Rima potpisana je 8. lipnja 1881. u Rimu Konvencija između Svete Stolice i Austro-Ugarske, kojom su preuređeni državno-crkveni odnosi u Katoličkoj crkvi u BiH. U Konvenciji sa Svetom Stolicom bilo je mnogo povijesnih, pravnih, političkih i međunarodnih promjena te crkve-

* Rad se zasniva na konzultaciji Kućnoga, dvorskog i državnog arhiva u Beču, Arhiva BiH u Sarajevu, Vatikanskoga tajnog arhiva i Arhiva Svetoga Zbora za širenje vjere (Propaganda fide) u Rimu. 
no-pravnih novosti u usporedbi s vremenima četiristoljetne okupacije Osmanskoga Carstva i duge ugnjetavačke islamske politike, simbolizirane u Milodraškoj Ahd-nami iz 1463. godine, kao i u usporedbi s vladavinom misijskoga prava, koji su bili na snazi u BiH do 1878., odnosno do 1881. godine. Među tim novostima posebno mjesto zauzimao je, svakako, privilegij imenovanja katoličkih biskupa. U ovome kratkom prilogu prikazan je državno-pravni i crkveno-pravni proces izbora i imenovanja prvoga biskupa u Hercegovini, fra Paškala $\mathrm{Bu}-$ conjića, po duhu spomenute Konvencije. U svojim trostrukim funkcijama, apostolskoga vikara u Hercegovini, biskupa mostarsko-duvanjskoga te konačno apostolskoga upravitelja trebinjsko-mrkanskoga, na koje je sukcesivno bio imenovan, najjasnije se očituje crkveno-državni karakter kako recepcije tako i realizacije potpisane Konvencije u Hercegovini. Buconjić, hercegovački franjevac, et pleno sensu crkveni čovjek i redovnik, zahvaljujući svome ugledu i vještini, uživao je veliko povjerenje kod Zemaljske vlade u Sarajevu, kod Zajedničkoga ministarstva financija u Beču i kod Cara osobno. Autor ne ulazi, namjerno, u ljudski, duhovni, redovnički, svećenički, pastoralni i biskupski profil fra Paškala Buconjića, najmanje u njegov odnos s dijecezanskim klerom, on to prepušta trenutačno drugim promatračima $\mathrm{i}$ istražiteljima. On nastoji prvenstveno prikazati kako biskup Buconjić uspijeva u skoro svim svojim biskupskim planovima s novom državnom vlašću, ali isto tako on ukazuje kako Austro-Ugarska u Buconjiću nalazi svoga najvjernijega katoličkog partnera u $\mathrm{BiH}$ i najpogodniju duhovnu osobu za promicanje njezinih crkveno-državnih nauma s Katoličkom crkvom u Hercegovini.

Ključne riječi: Hercegovina, Apostolski vikarijat u Hercegovini, Mostarsko-duvanjska biskupija, Trebinjsko-mrkanska biskupija, Konvencija između Svete Stolice i Austro-Ugarske, Apostolska bula Ex hac augusta Lava XIII., fra Paškal Buconjić.

\section{Uvod}

$\mathrm{Za}$ vrijeme četrdesetogodišnje austro-ugarske vladavine $\mathrm{u} \mathrm{BiH}$ došlo je dvaput do biskupskoga izbora i imenovanja u Hercegovini. Fra Paškal Buconjić, hercegovački franjevac, bio je najprije izabran i imenovan u siječnju 1880. godine apostolskim vikarom u Hercegovini, a u listopadu 1881. godine bio je izabran i imenovan prvim mostarsko-duvanjskim biskupom. Gotovo deset godina kasnije, u srpnju 1890. godine, imenovao ga je papa Lav XIII., uza suglasnost cara Franje Josipa, apostolskim upraviteljem Trebinjsko-mrkanske biskupije pro tempore (privremeno). Poslije njegove smrti u prosincu 1910. godine uslijedila je poduža upražnjenost 
biskupske stolice u Mostaru (sedes vacans). Istom, u veljači 1912. godine bio je izabran i imenovan novi mostarsko-duvanjski biskup fra Alojzije Mišić, franjevac Bosne Srebrene. U ovome prilogu autor pokušava prikazati trostruki izbor i imenovanje fra Paškala Buconjića u Hercegovini u svjetlu crkveno-pravnih i crkveno-državnih odnosa toga vremena.

\section{Izbori i imenovanja biskupa Buconjića}

\subsection{Povijesno-pravni preduvjeti}

Izbor biskupâ u Katoličkoj crkvi bio je i ostao veoma složen crkvenopravni, a u nekim zemljama i državno-pravni proces. Zaposjednućem Bosne i Hercegovine 1878. godine i potpisivanjem Konvencije između Austro-Ugarske i Svete Stolice 8. lipnja 1881. u Rimu, stvoreni su državno-pravni i crkveno-pravni uvjeti za biskupska imenovanja u novozaposjednutim zemljama $\mathrm{BiH} .{ }^{1}$ Do tada je za Crkvu u BiH vrijedilo izvanredno (misijsko) pravo, koje je bilo uvedeno osnivanjem Apostolskoga vikarijata 1735. godine te je predviđalo, garantiralo i štitilo izvanredno crkveno stanje i na postojeća misijska crkvena sjedišta promoviralo apostolske vikare. ${ }^{2}$ Osim izvanredne crkvene jurisdikcije apostolskih vikara

1 Konvencija (Ugovor) između Svete Stolice i Austro-Ugarske od 8. lipnja 1881. ostao je do danas dokument historijskih dimenzija za Katoličku crkvu u BiH. Potpisao ga je kardinal državni tajnik, Jacobini i austro-ugarski veleposlanik pri Svetoj Stolici, grof Paar. Konvencija je, kao i svaki drugi međudržavni i međunarodni ugovor, kompromisno rješenje dviju zainteresiranih strana. I osim davanja privilegija Caru od Svete Stolice, da može imenovati nadbiskupa, biskupe i kanonike u BiH na isti način kao u cijeloj Carevini, Konvencija je bila velik dobitak za Katoličku crkvu u BiH. Ona je služila do danas i služi još uvijek kao predložak za sve važnije crkveno-državne ugovore glede Katoličke crkve u BiH. Usp. HHStA Wien, Adm. Reg. F27/40. Nr. 84; Angelo Mercati (prir.), Raccolta di concordati su materie ecclesiastiche tra la Santa Sede e le autorità civili 1098-1914, I., Tipografia poliglotta vaticana, Città del Vaticano, 1954., str. 1014-1015; BERISLAV GAVRAnović, Uspostava redovite katoličke hijerarhije u Bosni i Hercegovini 1881. godine. Prilog političkoj historiji Austro-Ugarske Monarhije na Balkanu, Beograd, 1935., str. 196-202; ĐURO KoKšA, "Uspostava redovite hijerarhije u BiH 1881.", u: Petar Babić - Mato Zovkić (prir.), Katolička Crkva u Bosni i Hercegovini u XIX i XX stoljeću, (Studia Vrhbosnensia - 1), Vrhbosanska visoka teološka škola, Sarajevo, 1986., str. 21-60; Petar Vrankić, Religion und Politik in Bosnien und der Herzegowina (1878-1918), Ferdinand Schöningh, Paderborn, 1998., str. 469-472.

2 Bono Vrdoljak, Apostolski vikarijat u Bosni: 1735-1881, Doktorska disertacija u Ljubljani, Visoko, 1961.; Petar Vrankić, La Chiesa cattolica nella Bosnia ed Erzegovina al tempo del vescovo fra Raffaele Barišić (1832-1863), Pontificia Università Gregoriana Editrice, Roma, 1984., str. 55-64; Ist, Religion und Politik, str. 321-336. Nastanak misijskoga prava usko je povezan s kolonijalnom ekspanzijom krajem 15. i početkom 16. stoljeća te na poseban način s osnivanjem, širenjem i jačanjem Sve- 
u Bosni (1735.-1881.), u Hercegovini (1846.-1881.), postojala je cijelo vrijeme i redovna biskupska jurisdikcija u Trebinjsko-mrkanskoj biskupiji, koja nije bila ugašena za vrijeme osmanlijskoga zaposjednuća. ${ }^{3}$

Zahvaljujući dugim i napornim pregovorima između Beča i Rima te potpisivanju Konvencije između Svete Stolice i Austro-Ugarske od 8. lipnja 1881. u Rimu, mogao je papa Lav XIII. apostolskom bulom Ex hac augusta Principis Apostolorum cathedra ("S ovog uzvišenog prijestolja apostolskog Prvaka") od 5. srpnja 1881. ponovo uspostaviti redovitu hijerarhiju u $\mathrm{BiH} .{ }^{4}$ No, dok se u hrvatskoj historiografiji, osobito onoj bosansko-hercegovačke proveniencije, posebno ističe, slavi, citira i prenaglašava Papina bula Ex hac augusta, istovremeno se podcjenjuje ili se uopće ne poznaje značenje i uloga sklopljene Konvencije, ovoga, za Katoličku crkvu u BiH, fundamentalnoga međunarodnog ugovora, čiji je okvir i duh do danas ostao na snazi. ${ }^{5}$ Prije svega, treba jasno reći i priznati: Sve što je papa Lav XIII. bulom Ex hac augusta dokinuo, podigao, ustanovio i proglasio, nije činio, kako se obično misli, piše i dalje prepisuje ex plenitudine potestatis suae, nego duhom i snagom Konvencije u kojoj stoji: "Sveti Otac će pristupiti ponovnoj uspostavi crkvene hijerar-

toga Zbora za širenje vjere (Kongregacije Propagande) poslije 1622. godine. O početcima misijskoga prava može se više saznati u novijim radovima. Usp. RoBERTo SARTOR, Le convenzioni tra il vescovo diocesano e il superiore di un Istituto missionaria a norma del can. 790, $\$ 1,2^{\circ}$ del CIC, Editrice Pontificia Università Gregoriana, Roma, 2011., str. 11-40; Julio G. Arcía Martín, La formazione del diritto missionario durante il sistema tridentino (1563-1917), Marcianum Press, Venezia, 2013.

3 Usp. Bazilije PandžIć, De diocesi Tribuniensi et Mercanensi, Roma, 1952.; Isti, "Trebinjska biskupija u tursko doba", u: Ivica PuljIć (prir.), Tisuću godina Trebinjske biskupije, (Studia Vrhbosnensia - 2), Vrhbosanska visoka teološka škola, Sarajevo, 1988., str. 91-122; P. VRANkić, Religion und Politik, str. 337-338.

4 Osim originalnoga latinskog teksta sačuvanoga u arhivima Rima, Beča, Sarajeva te pojedinim biskupijskim arhivima $\mathrm{BiH}$, postoje i hrvatski prijevodi od kojih je najstariji iz 1883. godine, kojega je učinio i objavio nadbiskup Stadler u popisu svećenstva i župa. Svi noviji prijevodi svjesno su ili podsvjesno prešućena kopija ovoga prvog prijevoda. Usp. Imenik klera i župa Nadbiskupije Vrhbosanske i Biskupije Banjalučke za godinu 1883. Sarajevo, 1883., str. 4-20; LEON XIII., Ex hac augusta. Litterae apostolicae quibus hierarchia episcopalis in Bosnia et Herzegovina instituitur - Apostolsko pismo kojim se ustanovljuje biskupska hijerarhija u Bosni i Hercegovini, Biskupska konferencija Bosne i Hercegovine, Sarajevo, 2006.

5 "Dopo che l'Amministrazione della Bosnia e dell'Erzegovina è stata assunta dal Governo di S. Maestà Imperiale e reale Apostolica, la Santa Sede ed il Governo stesso hanno riconosciuto la necessità di provvedere agli interessi religiosi ed ai bisogni spirituali di quelle provincie, mediante un'organizzazione ecclesiastica, che meglio corrisponda alla nuova condizione di cose e renda più libero e più fruttuoso l'esercizio dell'alta missione della Chiesa a beneficio di quelle popolazioni." A. Mercati, Raccolta di concordati, str. 1014. 
hije u Bosni i Hercegovini."6 Samo u duhu i na temelju ove Konvencije mogao je Lav XIII. osnovati vrhbosansku crkvenu pokrajinu (metropoliju) s jednom nadbiskupijom i tri biskupije. Srednjovjekovna Bosanska biskupija nije bila time dokinuta nego je bila uzdignuta na stupanj nadbiskupije s naslovom Vrhbosna, sa sjedištem u Sarajevu.?

U Vrhbosanskoj nadbiskupiji, po Konvenciji, trebao se podići prvostolni kaptol s četiri kanonička mjesta uz godišnju dotaciju od 2000 forinti po osobi. U istoj nadbiskupiji moralo se podići pokrajinsko sjemenište za odgoj svjetovnoga svećenstva iz cijele metropolije. ${ }^{8}$ Novoodgojeni svjetovni svećenici trebali su vršiti svoju svećeničku službu i dušobrižničku brigu zajedno s redovničkim svećenstvom, kojemu je trebalo iskazivati dužno poštovanje zbog njegovih povijesnih zasluga za Crkvu. ${ }^{9}$ Vlada je stavila potrebna sredstva na raspolaganje za podizanje i uzdržavanje ovoga zavoda. ${ }^{10}$

6 "Il Santo Padre procederà al ristabilimento della gerarchia ecclesiastica nella Bosnia ed Erzegovina." Isto.

7 Leonis XIII Pontificis Maximi Acta, II, Romae, 1882., str. 288-312.

8 U Konvenciji nema neposrednoga spomena podizanja maloga (dječačkog) sjemeništa u BiH. Dječačko sjemenište u Travniku osnovano je na temelju carske odluke od 5. studenoga 1881., koju je Zajednički ministar financija, Szlávy, saopćio nadbiskupu Stadleru 19. prosinca 1881. Usp. ABiH Sarajevo, Präs. BH, Z1208/1881; Präs. BH 1542/1910. Ovaj nedostatak Konvencije, kojega nitko prije 1910. godine nije izravno primijetio i javno iznio, koštao je nadbiskupa Stadlera od 1910. do 1914. godine mnogo truda, napora i straha, jer se prijetilo zatvaranjem gimnazije i sjemeništa u Travniku. Dječačko sjemenište u Travniku, ne bez isusovačke krivice, bilo je proglašeno jezuitskom gimnazijom i na prijedlog Bosansko-hercegovačkoga sabora i uz potporu bosanskih franjevaca bilo je zaključeno, da se subvencija za Travničko sjemenište drastično smanji i ušteđena sredstva prenesu na Franjevačko sjemenište/gimnaziju u Visokom. Odluci bh. sabora, Zemaljske vlade i Zajedničkoga ministarstva financija u Beču usprotivio se car Franjo Josip. Sjemenište u Travniku bilo je spašeno, jer je Car smatrao da se odluka Sabora i Vlade protivi Konvenciji između Svete Stolice i Austro-Ugarske. Usp. Leo AsHLey Nicoll, Anton Puntigam S. J. Leben und Wirken eines Jesuiten in Bosnien, Philosophische Dissertation, Wien, 1970., str. 140-141; P. VRANkić, Religion und Politik, str. 726.

9 "Nell'Arcidiocesi di Sarajevo verrà aperto per ora e senza ritardo un Seminario provinciale che soddisfi ai bisogni non solo dell'Arcidiocesi, ma ancora delle altre diocesi suffraganee, affinché per questo mezzo si formino abili soggetti del Clero secolare, che si occupino alacremente del sacro ministero e nella cura delle anime insieme al Clero regolare, cui, attesi i lunghi servigi prestati alla Chiesa, sono da usarsi i dovuti riguardi." A. Mercati, Raccolta di concordati, str. 1015.

10 "Il Governo di Sua Maestà Imperiale e Reale Apostolica fornirà i mezzi occorrenti a tale istituto." Isto. 
Na prostoru Bosne, osim Vrhbosanske nadbiskupije, po Konvenciji bila je osnovana i Banjolučka biskupija s apostolskim upraviteljem, u nadi da će osnivanje biskupije pomoći podizanju i ostalih potrebnih institucija. ${ }^{11}$

U Hercegovini, gdje su odnosi bili mnogo jasniji i želje skromnije, prijedlozi apostolskih posjetitelja i Rimskih kongregacija bili su potpuno usvojeni, i u Konvenciji potvrđeni. Prije svega odlučeno je podizanje nove biskupije u gradu Mostaru, koja će nositi ime ovoga grada. ${ }^{12}$ Biskupija u Mostaru, koju će papa Lav XIII. preimenovati u Mostarsko-duvanjsku biskupiju, obuhvaćala je područje Apostolskoga vikarijata u Hercegovini, osnovanoga 1846. godine. U njezin naslov uključio je Lav XIII. i staru Duvanjsku biskupiju, koja se prvi put spominje 591. godine. ${ }^{13}$ I dalje je sačuvana najstarija postojeća biskupija na području BiH, Trebinjska, te je i nadalje bila povjerena na upravu dubrovačkome biskupu, dok se drukčije ne bude odlučilo između Beča i Svete Stolice. ${ }^{14}$ Konvencija je predviđala istovremeno podizanje stolnoga kaptola u Mostaru, ukoliko prilike to budu dopustile. ${ }^{15}$

Prema spomenutoj Konvenciji ostvaren je dobar i uravnotežen kompromis glede broja biskupija. Nova katolička crkvena pokrajina u BiH imala je nadbiskupiju sa sjedištem u Sarajevu i tri područne biskupije, jednu u Bosni i dvije u Hercegovini. Na temelju Konvencije vrhbosanska nadbiskupska stolica bila je dotirana godišnje s 8000, mostarska biskupska stolica sa 6000 i ona banjolučkoga upravitelja s 3000 forinti iz proračuna Zemaljske vlade u Sarajevu. Dubrovački biskup, kao apostolski upravitelj Trebinjske biskupije, bio je dotiran kao i drugi biskupi Zadarske me-

11 "Contemporaneamente si erigerà in Banjaluka una sede vescovile suffraganea di Sarajevo. Sua Santità per altro la farà governare provvisoriamente da un Amministratore Apostolico con carattere vescovile, nell'intento che si vada preparando convenientemente la fondazione degli istituti necessari ad una ben regolata diocesi." Isto, str. 1014.

12 "Nell'Erzegovina si erigerà un vescovato nella città di Mostar, che ne prenderà il nome." Isto.

13 Usp. Opći šematizam Katoličke Crkve u Jugoslaviji, Zagreb, 1975., str. 386. Ovdje ne mogu slijediti novija mišljenja pojedinih hrvatskih povjesničara. Usp. AnTE ŠKegro, Na rubu opstanka. Duvanjska biskupija od utemeljenja do uključenja u Bosanski apostolski vikarijat, Hrvatski institut za povijest - Dom i svijet, Zagreb, 2002., str. 130-132.

14 "La diocesi di Trebinje continuerà ad essere amministrata dal Vescovo di Ragusa fino a che fra la Santa Sede ed il Governo di Sua Maestà Imperiale e reale Apostolica siano si presi speciali accordi per una nuova sistemazione della medesima." A. Mercati, Raccolta di concordati, str. 1014.

15 "Essendo necessario che anche il Vescovo di Mostar sia circondato dal suo Capitolo, ne viene ammessa in principio la erezione, la quale avrà effetto appena le circostanze lo permetteranno." Isto. 
tropolije iz proračuna Zemaljske vlade za Dalmaciju. Gledajući brojčano stanje vjernika u $\mathrm{BiH}$ može se primijetiti sljedeće: Katolici u BiH, koji su 1879. godine po prvom službenom zemaljskom popisu stanovništva imali 209.391 duša ili 18,08 \% cijeloga stanovništva, bili su s četiri predviđene biskupije više nego zadovoljavajuće opskrbljeni, premda se u ono doba u Posavskoj (Posavini) veoma osjećala udaljenost od nadbiskupskoga sjedišta u Sarajevu. No ni danas, poslije 135 godina, nije Posavska postala bliža Sarajevu niti se Sarajevo približilo Posavskoj. ${ }^{16}$

Usporedivši broj vjernika i broj biskupija/eparhija i zbroj svih dotacija kako kod katolika tako i kod pravoslavaca na početku austro-ugarskoga zaposjednuća, dolazi se do saznanja da je Konvencija između Svete Stolice i Austro-Ugarske bila kudikamo povoljnija za Katoličku crkvu nego što je to bila Konvencija između Beča i Fanara za Pravoslavnu crkvu u BiH.

Austro-Ugarska kao pravna država preuzima svoje obveze prema zatečenim konfesijama i religijama u novozaposjednutim pokrajinama, $\mathrm{BiH}$, i sklapa s njihovim vrhovnim vjerskim poglavarima konkordate, konvencije ili ugovore po kojima se regulira njihov vjerski život ad extra. Predodžbe vjerskih poglavara: biskupa, metropolita, muftija, reisu-l-uleme, patrijarha i pape često se nisu poklapale s interesom liberalno-postjozefinistički uređene države, kakva je bila Austro-Ugarska. Ukoliko nije bilo moguće naći jedan zdravi interni kompromis između

16 Usp. K. und K. Gemeinsames Finanzministerium (prir.), Bericht über die Verwaltung von Bosnien und der Hercegovina 1906, Wien, 1906., str. 144-147; P. VRANkić, Religion und Politik, str. 469-474. Istovremeno, pravoslavni kršćani, koji su 1879. godine po istom popisu imali 496.485 duša ili 42,88 \% ukupnoga stanovništva, zadržali su tri već postojeće eparhije. Za njih je prema Konvenciji od 28. ožujka 1880. između Ekumenskoga patrijarhata u Carigradu i Austro-Ugarske bilo utvrđeno da se zadržavaju tri zatečene metropolije (eparhije) Zvorničkotuzlanska, Zahumsko-hercegovačka te Dabro-bosanska sa sjedištem u Sarajevu. Premda su ove tri eparhije, po grčkoj tradiciji imale naslov metropolije, samo je Dabro-bosanska eparhija u doba austrougarske vladavine bila uzdignuta na rang prave metropolije i tako bila i dotirana. Usp. K. und K. Gemeinsames FinAnZMINISTERIUM (prir.), Bericht über die Verwaltung von Bosnien und der Hercegovina 1906, str. 131-135; P. VRAnkić, Religion und Politik, str. 122-132. 
zainteresiranih strana, nadvladao je gotovo uvijek državni raison, koji nije poštedio ni katolike, ni pravoslavce, ni muslimane, ${ }^{17}$ ni židove ${ }^{18}$

Uza sve gore spomenuto, Konvencija je jasno definirala i biskupska imenovanja u $\mathrm{BiH}$ koja su odgovarala novom državnom i crkvenom uređenju, što je donekle predmet ovoga kratkog prikaza. U Konvenciji stoji: Sveti Otac, rimski biskup, iskazujući puno povjerenje i zahvalnost Apostolskome veličanstvu, caru i kralju, koji svojim zalaganjem i velikodušnošću tako djelotvorno pridonosi dobru i rastu Crkve, podijelio mu je povlasticu (privilegij) imenovanja nadbiskupa i biskupa u $\mathrm{BiH} .{ }^{19}$ Ovaj privilegij nije bio nikakva novost, koja je bila istom uvedena $\mathrm{u} \mathrm{BiH}$, nego je vrijedio od pamtivijeka u cijeloj Habsburškoj Monarhiji i njezinim zemljama kao što su Dalmacija, Hrvatsko-Slavonska, Primorska (Küstenland), Kranjska, Koruška, Štajerska, Ugarska, Transilvanska, Moravska, Češka, Šleska, Galičinska, Bukovinska i sve nasljedne Habsburške zemlje te je bio uvijek potvrđivan od Svete Stolice prigodom preuređenja crkvenih prilika u spomenutim zemljama, tako konkretno u južnoj Hrvatskoj 1828. za Zadarsku crkvenu pokrajinu, ${ }^{20}$ i 1852. godine za Hrvatsko-Slavonsku crkvenu pokrajinu. ${ }^{21}$

17 Do konačnoga ustrojstva islamske vjerske zajednice došlo je u jesen 1882. godine nakon imenovanja prvoga reisu-l-uleme i odluke o formiranju, školovanju i odgoju ulema medžlisa u BiH. Usp. K. und K. Gemeinsames Finanzministerium (prir.), Bericht über die Verwaltung von Bosnien und der Hercegovina 1906, str. 125; NusRet ŠEHIĆ, Autonomni pokret Muslimana za vrijeme austrougarske uprave u Bosni i Hercegovini, Svjetlost, Sarajevo, 1980., str. 19-30.

$18 \mathrm{Za}$ židove španjolskoga podrijetla (sefarde), koji su se već u 16. stoljeću naselili u $\mathrm{BiH}$, bio je odobren statut 1882. godine, za židove njemačkoga, austrijskoga, ugarskoga i slavenskoga podrijetla (aškenaze) bile su utemeljene vjerske općine 1883. u Sarajevu i 1884. godine u Banjoj Luci. Usp. K. und K. Gemeinsames FinanzminiSTERIUM (prir.), Bericht über die Verwaltung von Bosnien und der Hercegovina 1906, str. 150.

19 "Il Santo Padre, in base al nuovo ordine di cose stabilitosi nella Bosnia e nella Erzegovina, volendo mostrare piena fiducia e riconoscenza verso la Sua Maestà Imperiale e Reale Apostolica che, colla sua generosità e con i suoi impegni per lo avvenire, contribuisce sì efficacemente al bene ed incremento di quelle Chiese, concede alla stessa Maestà Sua il privilegio di nomina dell'Arcivescovo e dei Vescovi nella Bosnia e nell'Erzegovina." A. Mercati, Raccolta di concordati, str. 1015.

20 Opći šematizam Katoličke Crkve u Jugoslaviji, str. 198.

21 Isto, str. 51. 


\section{Izbor i imenovanje fra Paškala Buconjića apostolskim vika- rom u Hercegovini}

Nepunu godinu nakon zaposjednuća $\mathrm{BiH}$ umire na krizmenom pohodu 27. srpnja 1879. u Konjicu, stari apostolski vikar u Hercegovini, nasljednik apostolskoga vikara i biskupa fra Rafe Barišića, biskup fra Anđeo Kraljević (1807.-1879.). Starost, iscrpljenost, neprekinute napetosti sa starješinstvom Hercegovačke franjevačke kustodije na Širokom Brijegu, predvođeno kustodom fra Paškalom Buconjićem, ${ }^{22}$ neuspjeli ishod apostolskoga pohoda po Hercegovini pomoćnoga splitskog biskupa

22 Fra Paškal (Stjepan) Buconjić (Drinovci), 2. IV. 1834. - Mostar, 8. XII. 1910.), hercegovački franjevac, profesor filozofije na Franjevačkome glavnom učilištu Ara Coeli u Rimu (1860.-1867.), kustod Hercegovačke franjevačke kustodije (1874.-1879.), naslovni biskup Magydusa i apostolski vikar u Hercegovačkome vikarijatu (1880.1881.), prvi mostarsko-duvanjski biskup (1881.-1910.) s geslom: Sve za vjeru i za domovinu. Buconjić je bio imenovan 1890. godine apostolskim upraviteljem Trebinjsko-mrkanske biskupije. Stjepan Buconjić je stupio u franjevački red 1851. godine, te je uzeo ime fra Paškal. Temeljno školsko obrazovanje stekao je na Čerigaju i na Širokom Brijegu te je odatle bio upućen u Ferraru, u Italiji, gdje je završio filozofskoteološke studije. U Ferrari je ređen za svećenika 1856. i u istom je gradu postigao 1859. godine naslov lektora (profesora) filozofije. Poslije lektorske službe na franjevačkome Glavnom učilištu Ara Coeli u Rimu, bio je vraćen 1867. godine u Hercegovinu. Tu je radio kao predavač u samostanskoj školi na Širokome Brijegu do 1871. i kao župnik u Drinovcima do 1874. godine. Buconjić je bio izabran za poglavara (kustoda) Hercegovačke franjevačke kustodije. Posebno se istaknuo u doba ustaničkih godina 1875.-1876. kao posrednik ali kao branitelj katolika Hrvata u Hercegovini protiv osmanskih, crnogorskih i srpskih pretenzija. Tom prigodom objavio je kratki spis: Un cenno semplice sui gravami causa principale dell'insurrezioni delle popolazioni cristiane, Mostar, 1875., koji je trebao poslužiti međunarodnome povjerenstvu da sazna prave razloge za ustanak kršćanskih podanika protiv osmanlijskoga ugnjetavanja. Kao hercegovački franjevački kustod umiješao se neopravdano u jurisdikciju apostolskoga vikara fra Anđela Kraljevića te došao u veoma oštar sukob s njime. Budući da je ovaj sukob mogao poprimiti slične okvire nekadašnje Barišićeve afere, izazvao je odlučnu reakciju Svetoga Zbora za širenje vjere, koji je poslao apostolskoga pohoditelja, splitsko-makarskoga pomoćnog biskupa Kazimira Forlanija, u Hercegovinu. Apostolski pohod obavljen je u proljeće 1878. bez ikakvih negativnih sankcija za kustoda Buconjića. Prema mišljenju vikara Kraljevića, pohod je bio beskoristan: Nullum effectum video visitationis Forlani, pisao je Kraljeviću Rim. Usp. AP. SC Bosnia, vol. 16, fol. 929v. Na Buconjićevo mjesto bio je izabran novi kustod fra Marijan Zovko i time je cijela stvar bila zataškana. Usp. Radoslav Glavaš, Biskup o. Paškal Buconjić, prigodom tridesetogodišnjice biskupovanja 1880-1910., Mostar, 1910.; MARko Perić, "Život i rad mostarsko-duvanjskih i trebinjsko-mrkanskih biskupa u zadnjih 100 godina", u: Petar Babić - Mato Zovkić (prir.), Katolička crkva u Bosni i Hercegovini u XIX i XX stoljeću, Sarajevo, 1986., str. 275-281; P. VRAnkić, Religion und Politik, str. 336, 411-413; ANDRIJA NIKIĆ - RoBert Jolić, "Buconjić, Paškal Stjepan", u: Hrvatski franjevački biografski leksikon, Leksikografski zavod Miroslav Krleža, Zagreb, 1910., str. 91-92. 
Kazimira Forlanija iz Makarske, ${ }^{23}$ neposlušnost pojedinih franjevaca u pastoralnoj skrbi vjernika, prekinuli su životni put ovoga prekaljenog borca za prava katolika u osmanskoj Hercegovini i neustrašivoga branitelja prava hercegovačkih franjevaca u njihovu polustoljetnom sukobu s nadmoćnijom subraćom iz Bosne Srebrene, bosanskim ujacima. ${ }^{24}$ Neposredno poslije sprovoda biskupa Kraljevića, Starješinstvo hercegovačkih franjevaca, predvođeno kustodom fra Marijanom Zovkom, dogovorilo je strategiju i zamolilo subraću, sve župnike i sve članove kustodijskoga vodstva, da se 13. kolovoza 1879. okupe u samostanu na Širokom Brijegu da bi raspravili nastalu situaciju i predložili kandidate za upražnjeno mjesto apostolskog vikara u Hercegovini. ${ }^{25}$ Tom prilikom Starješinstvo hercegovačkih franjevaca ne trudi se rasvijetliti neznanje i neupućenost nove vlasti u ovoj crkveno-pravnoj proceduri misijskoga karaktera i javlja samo da mora poslati u Rim ternu, prijedlog od tri kandidata, za budućega apostolskog vikara. ${ }^{26}$ Okružni predstojnik, Teodorović (Todorović?), saznavši za ovaj sastanak, saopćuje Starješinstvu Kustodije 12. kolovoza da će njihov prijedlog trojice kandidata biti važeći ukoliko način izbora (Wahlmodus) bude u skladu sa zakonima i odobren od Zemaljske vlade. ${ }^{27}$ Okružna vlast u Mostaru poslala je isto saopćenje i vojvodi od Württemberga, predstojniku Zemaljske vlade u Sarajevu, i zatražila pojašnjenje. Vojvoda od Württemberga, proslijedi telegrafski vijest u Beč i primijeti da će prijedlog trojice kandidata biti

23 Usp. P. Vrankić, Religion und Politik, str. 411-413.

24 P. VRankić, La Chiesa cattolica, str. 217-255.

25 Vojvoda od Württemberga, ministru Hofmannu u Beč, Sarajevo, 13. 8. 1879. ABH Sarajevo, GFM BH 3968/1879.; P. VRANkić, Religion und Politik, str. 507. U jesen 1991. godine imao sam u planu posjetiti Arhiv Provincije u Mostaru. Čak je i termin posjeta bio dogovoren i trebao sam popuniti ove podatke iz spisa i svjedočanstava hercegovačkih franjevaca. No, nemiri i rat u Hrvatskoj spriječili su me u ovoj namjeri. Ovdje zahvaljujem dragom prijatelju, profesoru fra Andriji Nikiću, na svim uslugama i u ono doba ponuđenoj pomoći.

26 Po dekretu Svetoga Zbora za širenje vjere od 15. 8. 1852. bio je reguliran postupak poslije smrti apostolskoga vikara u Hercegovini. Kustod Hercegovačke kustodije bio je dužan sazvati sjednicu, sastavljenu od svojih savjetnika (diskreta), generalnoga vikara Apostolskoga vikarijata i svih župnika i u župnoj pastvi aktivnih svećenika (curati), i tajnim glasovanjem predložiti trojicu dostojnih otaca kao nasljednike pokojnika. Kustod je bio dužan pripremiti listu kandidata, (terna), u roku od osam dana i poslati je pročelniku Svetoga Zbora za širenje vjere i Generalnome Ministru reda. ASV, AAEESS Austria-Ungheria (1879-1881), pos. 506, fasc. 233, fol. 106v. U ovom slučaju kustod Zovko postupio je ispravno i u duhu dekreta Svetoga Zbora za širenje vjere.

27 Kopija pisma kustoda Zovke Ministru reda, 15. 8. 1879. ASV, AAEESS AustriaUngheria (1879-1881), pos. 506, fasc. 233 , fol. $108 \mathrm{v}$. 
važeći, ukoliko način izbora bude u skladu sa zakonima i odobren od Zemaljske vlade. ${ }^{28}$ Predstojnik Bosanskoga ureda u Zajedničkom ministarstvu financija u Beču, barun Kraus, odgovara da on podrazumijeva zakonsku sukladnost izbora apostolskoga vikara, do nastupa promjene sadašnjega stanja u dogovoru sa Svetom Stolicom, u poštivanju dosadašnjih uobičajenih postupaka. ${ }^{29}$ Drugim riječima, odgovor iz Beča odobravao je indirektno postupak Starješinstva Kustodije.

U međuvremenu, na Širokom Brijegu sabrani franjevci predložiše 13. kolovoza 1879. trojicu kandidata sa sljedećim brojem glasova: fra Paškal Buconjić 27, fra Nikola Šimović 17 i fra Lujo Radoš 7 glasova. Kustod Zovko poslao je 15. kolovoza 1879. listu predloženih kandidata Pročelniku Svetoga Zbora za širenje vjere, kardinalu Simeoniju ${ }^{30}$ i Ministru Franjevačkoga reda u Rimu, fra Bernardinu iz Portogruara. ${ }^{31}$ Okružna vlast u Mostaru proslijedila je sa svoje strane vojvodi od Württemberga listu kandidata, ali s drugim brojem glasova, koju je dobila najvjerojatnije od svojih doušnika iz redova hercegovačkih franjevaca. Ona je glasila: fra Paškal Buconjić 25 glasova, fra Nikola Šimović ${ }^{32}$ isto tako

28 Vojvoda od Württemberga, ministru Hofmannu u Beč, Sarajevo, 13. 8. 1879. ABH Sarajevo, GFM BH 3968/1879.; P. VRAnkić, Religion und Politik, str. 507.

29 "Ich verstehe unter gesetzmäßig, bis zur Änderung des Status quo im Einvernehmen mit dem Hl. Stuhl, die Beachtung der bisher üblichen Modalitäten." Telegram baruna Krausa vojvodi od Württemberga, Beč, 13. 8. 1879. ABH Sarajevo, GFM BH 3968/1879.; P. VRankić, Religion und Politik, str. 507.

30 ASV, AAEESS Austria-Ungheria (1879-1881), pos. 506, fasc. 233, fol. 108r-v; P. VRAnkić, Religion und Politik, str. 507.

31 ASV, AAEESS Austria-Ungheria (1879-1881), pos. 506, fasc. 233, fol. 108v-109v; P. VRANKIĆ, Religion und Politik, str. 507.

32 Šimović Nikola (Zvirovići 25. IV. 1839. - Mostar 10. IX. 1912.) ugledni hercegovački franjevac, studirao je u Perugi, u Italiji, gdje je bio profesor teologije (1860.1866.). Poslije povratka u Hercegovinu bio je tajnik apostolskom vikaru Kraljeviću (1866.-1868.), župnik na Humcu (1868.-1876.), župnik u Mostaru (1876.-1889.), župnik u Međugorju (1895.-1899.), zadnji kustod Hercegovačke franjevačke kustodije (1889.-1992.) i prvi provincijal Hercegovačke franjevačke provincije (1892.1895.), dugogodišnji generalni vikar Mostarsko-duvanjske biskupije (1880.-1889. i 1899.-1912.). U svoje vrijeme bio je, bez sumnje, uz biskupa Buconjića jedan od najsposobnijih hercegovačkih franjevaca. To se vidi po tome što ga je Buconjić, premda mu je prije bio konkurent, imenovao generalnim vikarom (tu je službu obavljao dugi niz godina) i posebno kada ga je 1910. godine predložio za biskupa koadjutora cum iure successionis. Usp. P. VRankić, Religion und Politik, str. 514; RoBert Jolıć, "Šimović, Nikola", u: Hrvatski franjevački biografski leksikon, Leksikografski zavod Miroslav Krleža, Zagreb, 2010., str. 519. 
25 glasova i fra Lujo Radoš 17 glasova. ${ }^{33}$ Vojvoda od Württemberga proslijedio je telegrafski ovu listu u Beč 21. kolovoza. U međuvremenu Zajedničko Ministarstvo financija u Beču obavijestilo je Ministarstvo vanjskih poslova o namjerama i planovima hercegovačkih franjevaca i zamolilo za pravno razjašnjenje. Službeni Beč, koji je naredio da se izvidi što se događa u Hercegovini, saznao je preko svoga veleposlanstva u Rimu da Starješinstvo (kustod i njegova četiri savjetnika) hercegovačkih franjevaca nije reklo istinu Okružnoj vlasti u Mostaru. Odgovor iz Rima nije ostavljao prostora nikakvoj dodatnoj sumnji: niti pročelnik Svetoga Zbora za širenje vjere, niti Glavni ministar reda, nisu tražili od hercegovačkih franjevaca njihov prijedlog, odnosno ternu kandidata, za novoga apostolskog vikara. ${ }^{34}$ Tom prilikom saznao je veleposlanik da Sveta Stolica ne smatra da je došlo pravo vrijeme za imenovanje apostolskoga vikara u Mostaru. Istovremeno mu je bilo potvrđeno da će se ovo imenovanje zasigurno obaviti u potpunoj suglasnosti s Carskom vladom u Beču i da će izbor pasti na osobu koja će biti po volji vlade. ${ }^{35}$

Ohrabren ovim vijestima iz Beča vojvoda od Württemberga započeo je studirati listu predloženih kandidata i njihovu pozadinu. Već 28. rujna 1878. on preporučuje imenovanje fra Paškala Buconjića za apostolskoga vikara u Hercegovini. Uz druge izvore, on se dao posavjetovati i s tadašnjim apostolskim vikarom u Bosni, biskupom fra Paškalom Vuičićem, koji je bez oklijevanja preporučio fra Paškala Buconjića. ${ }^{36}$ Barun Kraus iz Bosanskoga ureda proslijedio je ovu preporuku 19. listopada 1879. ministru vanjskih poslova, Juliju Andrássyju. Pročelnik Kraus nije propustio priliku naglasiti Buconjićevu "podobnost", tj. potpunu odanost Caru i Monarhiji, što je u ono vrijeme više značilo nego bilo kakva velika

33 Različiti broj glasova u listama za pojedine kandidate teško je danas objasniti. Fra Nikola Šimović bio je u to doba župnik u Mostaru i prijateljevao je s okružnim predstojnikom. Najvjerojatnije je ovaj preko Šimovića dobivao svoja saznanja što se događalo u Kustodiji i među hercegovačkim franjevcima. U poznatom crkvenom sporu između apostolskoga vikara Kraljevića s kustosom Buconjićem i njegovim partizanima, koji je prinudio Svetu Stolicu da pošalje apostolskoga pohoditelja u Hercegovinu, Śimović se pokazao kao Kraljevićev sljedbenik. Tako je Šimović bio jedini pravi protukandidat agilnom Buconjiću. Usp. P. VRankić, Religion und Politik, str. 507.

34 Telegram baruna Krausa vojvodi od Württemberga, Beč, 12. 9. 1879. ABH Sarajevo, GFM BH 4545/1879.; P. VRankić, Religion und Politik, str. 508.

35 P. VRankić, Religion und Politik, str. 508.

36 Vojvoda od Württemberga Zajedničkom Ministarstvu financija u Beču, Sarajevo, 28. 9. 1879. ABH Sarajevo, LR Präs. 2096/1879.; P. VRAnkić, Religion und Politik, str. 508. 
moralna, duhovna ili intelektualna prikladnost izabranika. ${ }^{37}$ No, i hercegovački franjevci, budući da su znali gdje će se imenovanje odlučiti, ne ostadoše skrštenih ruku. Kustod Zovko pohiti u austro-ugarski konzulat u Mostar i predade preporuku za Buconjića upućenu direktno caru Franji Josipu. Zanimljivo je da se kustod Zovko služi starom austro-ugarskom institucijom, u kojoj je imao poznanstva iz vremena prije zaposjedanja zemlje, što jasno pokazuje da se on nije još bio navikao na novouspostavljenu redovnu austro-ugarsku upravu u BiH, Zemaljsku vladu u Sarajevu i Okružnu vlast u Mostaru. Drugi razlog obraćanja na konzulat u Mostaru može se protumačiti tako da kustod Zovko nije imao povjerenje u okružnoga predstojnika Teodorovića. Ovaj je najvjerojatnije, u franjevačkom internom natjecanju za stolicu apostolskoga vikara u Hercegovini, podržavao fra Nikolu Šimovića protiv fra Paškala Buconjića. On je već u proljeće 1879. predlagao smjenjivanje Kraljevića i imenovanje Šimovića za biskupskoga vikara u Hercegovini. ${ }^{38}$ Snažne preporuke iz Sarajeva i Mostara potaknule su pročelnika u Bosanskoj Komisiji, Benjamina Kállaya, da zamoli ministra vanjskih poslova Hofmanna, da poradi u Rimu na imenovanju fra Paškala Buconjića za apostolskoga vikara u Hercegovini. ${ }^{39}$ No Ministarstvo vanjskih poslova, koje je već u rujnu bilo informirano iz Mostara o prikladnosti Buconjića, bilo se već potrudilo u Rimu preporučiti dotičnoga franjevca za mjesto apostolskoga vikara u Hercegovini. Barun Seiller, otpravnik poslova austro-ugarskoga veleposlanstva pri Svetoj Stolici u Rimu, predaje 7. studenoga 1879. odgovarajuću diplomatsku notu kardinalu državnom tajniku, Lorenzu Nini, i preporučuje mu veoma toplo Buconjića, gvardijana samostana na Humcu. Seiller naglašava u spomenutoj diplomatskoj noti da crkveni velikodostojnici, osim karakteristika koje od njih traži Crkva, moraju izraziti svoju odanost vladi. Stoga moli barun Seiller da Buconjić, budući da ima sva tražena svojstva koja zahtijeva kako Crkva tako i Vlada, bude imenovan apostolskim vikarom u Hercegovini. U preporuci, koja je jedna vrsta hvalospjeva u čast fra Paškala Buconjića, koju donosimo u bilješci, nalaze se uobičajene fraze iz sličnih diplomatskih dokumenata. ${ }^{40}$

37 Barun Kraus ministru Andrássyu, 19. 10. 1879. ABH Sarajevo, GFM BH 4974/1879.; P. VRAnkić, Religion und Politik, str. 508.

38 Teodorović Zemaljskoj vladi u Sarajevu, 5. 4. 1879. ABH Sarajevo, GFM BH 1780/1879.; P. VRankić, Religion und Politik, str. 572.

39 Pročelnik Kállay ministru Hofmannu, 25. 11. 1879. ABH Sarajevo, GFM BH 6034/1879.; P. VRAnKić, Religion und Politik, str. 508.

40 "Le P. Bukonic (sic!) doué d'une profonde érudition, d'une grande énergie de caractère et du don de la représentation pourrait en sa qualité de Vicaire Apo- 
U preporuci baruna Seillera, koju je bez sumnje dobio iz Beča, treba spomenuti i dvije neobične stvari. Naime, svima je poznato da je u franjevačkoj historiografiji u BiH rasprostranjeno mišljenje, da je "Austrija" navodno od samoga početka ignorirala, zapostavljala i uklanjala franjevce iz župne pastve, crkvene uprave i crkvenih služba. Apostolski vikar u Bosni, fra Paškal Vuičić, čak je stiliziran kao "prva žrtva i prvi mučenik okupatorskog austrijskog režima". ${ }^{41}$ No ovdje vidimo da je on službeno pitan od austro-ugarskih vlasti u $\mathrm{BiH}$ o Buconjićevoj prikladnosti za mjesto apostolskoga vikara u Mostaru i da je njegovo mišljenje bilo odlučujuće, što se tiče crkvenoga autoriteta, budući da je Vuičić u ovo doba bio jedini crkveni autoritet u punom smislu riječi u Katoličkoj crkvi u BiH. Znači, apostolski vikar Vuičić nije progonjen i omalovažavan od austro-ugarske administracije, nego, kako se kasnije ispostavilo, od bosanskih franjevaca, koji ga nisu mogli trpjeti zbog njegova "dalmatinskog podrijetla" i takozvane "rimske i ugarske orijentacije". Zanimljivo je da je apostolski vikar Vuičić imao najljućega protivnika u svome poluzemljaku fra Grgi Martiću, samopozvanom predstavniku katolika u Sarajevu, i u njegovu odanom prijatelju i zaštitniku, biskupu Strossmayeru, $\mathrm{u}$ Đakovu. ${ }^{42}$

stolique rendre des services signalés tant à l'Eglise qu'au Gouvernement. Aussi son élévation à cette dignité ne manquerait pas de produire, au dire de $\mathrm{Mgr} \mathrm{Vu}$ icic, une très-bonne impression sur les habitants catholiques de l'Herzégovine. Le Gouvernement d'Autriche-Hongrie en se fiant aux renseignements qui lui ont été fournis à ce sujet avec la plus parfaite impartialité a donc toutes les raisons de s'intéresser plus vivement à voir le choix du St Siège s'arrêter sur le P. Bukonic (sic!), lequel a réuni la majorité des suffrages des Franciscains et du Clergé séculier en Herzégovine, pour obtenir la dignité du Vicaire Apostolique à Mostar." ASV, AAEESS Austria-Ungheria (1879-1881), pos. 506, fasc. 233, fol. 110r; P. VRANKIĆ, Religion und Politik, str. 508.

41 B. Gavranović, Uspostava redovite katoličke hijerarhije, str. 147-174.

42 Najgore optužbe, u šezdeset točaka, protiv apostolskoga vikara u Bosni, fra Paškala Vuičića, sastavio je, nažalost, bosanski franjevac hercegovačkih korijena, fra Grga Martić, te ih dao potpisati od svoga malo prikraćenog subrata iz kreševskoga samostana, fra Grge Franičevića i proslijediti na Sveti Zbor za širenje vjere u Rim. Optužbe su bile takve naravi da je Sveti Zbor naredio apostolskom pohoditelju u Hercegovini, biskupu Forlaniju, da obavi hitno apostolski pohod i u Apostolskom vikarijatu u Bosni i u Provinciji Bosni Srebrenoj. Martićeve optužbe protiv vikara Vuičića prihvaćao je bezrezervno i biskup Strossmayer u Đakovu te ih je s uvjerenjem slao u Rim, Svetoj Stolici, misleći da će tako Martiću osigurati buduću biskupsku stolicu u Sarajevu. Naime, Strossmayer je otvoreno špekulirao na nešto puno važnije: povratiti jurisdikciju nad starom Bosanskom biskupijom u krilo đakovačkoga biskupa. Dok su franjevačke i Strossmayerove optužbe protiv vikara Vuičića bile uglavnom moralne, pastoralne i socijalne naravi, dotle su optužbe austrijskih konzularnih i političkih krugova bile pretežno političke naravi, 
Još čudnija i smješnija ispada tvrdnja baruna Seillera da je Buconjić imao iza sebe većinu glasova franjevaca i svjetovnoga klera u Hercegovini, "lequel a réuni la majorité des suffrages des Franciscains et du Clergé séculier en Herzégovine". U tadašnjem Apostolskom vikarijatu u Hercegovini nije bilo nijednoga svjetovnog svećenika, nisu bili poželjni i nitko se nije trudio ni u Hercegovini ni u Rimu da budu prisutni u Vikarijatu. Ne djeluje uvjerljivo jedna danas sanjarska ideja da su eventualno okružne vlasti ili c.i k. konzulat u Mostaru pitali biskupijski kler u Trebinjskoj biskupiji, njihova provikara, don Lazara Lazarevića, dubrovačkoga biskupa, Ivana Zaffrona, kao susjede, dušobrižnike i upravitelje Trebinjske biskupije, što bi bilo logično, da je bilo više logike u kanonskom procesu oko izbora Paškala Buconjića za apostolskoga vikara u Hercegovini. Teško je danas utvrditi je li Seillerova tvrdnja u diplomatskoj noti, koju je dobio iz Beča, da je Buconjić imao iza sebe većinu glasova franjevaca i svjetovnoga klera u Hercegovini, plod bečke mašte i prijevare ili plod hercegovačke podvale, nastale na Širokom Brijegu ili možda u Mostaru, u austro-ugarskome konzulatu. ${ }^{43} \mathrm{Uz}$ ove preporuke dobio je Buconjić još jedno veliko crkveno priznanje. Apostolski pohoditelj Forlani opisao je Buconjića kao redovnika punog revnosti i revnog zagovarača redovničke discipline, ukrašenog dobrom naukom, budući da je bio lektor u Ara Coeli i vrijedan župnik u Drinovcima, te ga preporučuje za biskupa u Trebinju, ukoliko bude tamo imenovan biskup. ${ }^{44}$

Državno tajništvo Svete Stolice proslijedilo je molbu i prijedlog austrougarskog veleposlanstva na Sveti Zbor za širenje vjere, budući da se Katolička crkva u BiH još uvijek vodila kao misijsko područje i tako bila podložna jurisdikciji ovoga rimskog dikasterija. Pročelnik Simeoni, 20. studenoga 1879., predstavio je listu kandidata papi Lavu XIII. Ovaj zapovijedi da se imenovanje Buconjića odluči na sjednici Svetoga Zbora za širenje vjere, po misijskom pravu, još vladajućem crkvenom pravu u zaposjednutoj $\mathrm{BiH} .{ }^{45}$ Papin prijedlog je bio razmatran na sjednici 22 . prosinca 1879. i po mišljenju kardinala Howarda, izvjestitelja, postojalo

predbacujući mu čas prougarsko, čas antiaustrijsko raspoloženje. Usp. AP, SC Bosnia, vol. 16, fol. 826r-831v; P. VRANKIć, Religion und Politik, str. 413-414.

43 ASV, AAEESS Austria-Ungheria (1879-1881), pos. 506, fasc. 233, fol. 110r; P. VRANkić, Religion und Politik, str. 508-509.

44 "qualora si dovesse nominare un Vescovo per la Diocesi di Trebinje, non esiterei a proporre l'attuale Custode P. Pasquale Buconjic, pieno di zelo e sostenitore zelante della disciplina monastica, come anche adorno di buona dottrina, fu una volta lettore in Araceli e poi parroco premuroso a Drinovci in Erzegovina." ASV, AAEESS Austria-Ungheria (1879-1881), pos. 506, fasc. 233, fol. 107v.

45 Isto, 107r. 
je jedno jedino pitanje: "Da li i kojeg od predloženih subjekata priliči predočiti Njegovoj Svetosti za ispražnjeni Vikarijat u Hercegovini." ${ }^{\prime 6}$ Odluku rimskih stožernika olakšao je ministar reda, fra Bernardin iz Portogruara, svojom toplom preporukom Buconjića za upražnjeno mjesto u Hercegovini. ${ }^{47}$ I sama intonacija Howardove ponencije bila je tako složena da je u gotovo svakom retku odisala, bez ikakve kritičnosti, dubokom privrženošću za fra Paškala Buconjića. ${ }^{48}$ Kardinali odlučiše u spomenutoj sjednici zamoliti papu Lava XIII. da imenuje Buconjića apostolskim vikarom u Hercegovini i biskupom in partibus infidelium ("u krajevima nevjernika"). U službenoj audijenciji 11. siječnja 1880., u kojoj je primio tajnika Zbora za širenje vjere, nadbiskupa Ignacija Masottija, udovoljio je papa Lav XIII. prijedlogu spomenutoga zbora kardinala i potvrdio njihovu želju. Državno tajništvo Svete Stolice požurilo se 17. siječnja izvijestiti austro-ugarsko veleposlanstvo u Rimu o izboru Buconjića. ${ }^{49}$ Nakon što je Sveti Zbor za širenje vjere izdao svoj dekret 24. siječnja 1880. o imenovanju vikara Buconjića, ispostavilo je Tajništvo brevea Svete Stolice 30. siječnja 1880. dva dekreta, prvi o imenovanju fra Paškala Buconjića apostolskim vikarom u Hercegovini ${ }^{50}$ i drugi o njegovu imenovanju naslovnim biskupom Magydusa in partibus infidelium. ${ }^{51}$

Beč je pravovremeno izvijestio Zemaljsku vladu u Sarajevu i njezina predsjedavajućeg, generala Dahlena, o izboru i imenovanju u Mostaru. ${ }^{52}$ Budući da između Svete Stolice i Austro-Ugarske Monarhije nije još postojao nikakav državnopravni ugovor o pravnom položaju Katoličke crkve u BiH, izbor i imenovanje fra Paškala Buconjića provedeno je prema izvanrednom crkvenom pravu (misijskom pravu) u mjerodav-

46 "Se e quale dei proposti soggetti converrà presentare a S. S. pel vacante Vicariato della Erzegovina." ASV, AAEESS Austria-Ungheria (1879-1881), pos. 506, fasc. 233, fol. 107v; P. VRankić, Religion und Politik, str. 509.

47 Komentirajući prispjelu listu od trojice hercegovačkih kandidata za mjesto Apostolskoga vikara u Mostaru piše fra Bernardin iz Portogruara, 23. 11. 1879.: "però il sottoscritto crederebbe giusto e conveniente di dare la preferenza al padre Pasquale Buconjic, che meritamente fu posto in primo luogo della terna". Isto, fol. 110v.

48 ASV, AAEESS Austria-Ungheria (1879-1881), pos. 506, fasc. 233, fol. 106r-107v; P. VRAnkiĆ, Religion und Politik, str. 509.

49 ABH Sarajevo, GFM BH 436/1880.; P. VRankić, Religion und Politik, str. 509.

50 ASV, Arch. Brev. 1880., fol. 376r; Remigius Ritzler - Pirminus Sefrin, Hierarchia catholica medii et recentioris aevi, VIII., Padova, 1978., str. 359-360; P. VRANKIĆ, Religion und Politik, str. 509.

51 ASV, Arch. Brev. 1880., fol. 353r, 360v; R. Ritzlen - P. SEFrin, Hierarchia catholica, VIII., str. 359; P. VRANkić, Religion und Politik, str. 509.

52 ABH Sarajevo, GFM BH 436/1880.; P. VRankić, Religion und Politik, str. 509. 
nosti Svetoga Zbora za širenje vjere te uza suglasnost Beča, koji je preko svojih administrativnih tijela sudjelovao u izboru. Stoga Sveta Stolica nije poslala papinski breve na ruke vlade u Beču ili u Sarajevu, nego izravno novoimenovanome apostolskom vikaru Buconjiću u Mostar, na adresu njegova prethodnika fra Anđela Kraljevića.

Cijeli postupak Svete Stolice i vlade u Beču odvijao se u korektnome međusobnom poštovanju novonastaloga državnog prava i političkoga poretka te još važeće crkveno-pravne tradicije u BiH. U međuvremenu, Buconjić, dobivši rimske dokumente, zaputio se u Zagreb i dogovorio je biskupsko ređenje, koje je obavio zagrebački nadbiskup, kardinal Mihalović, 19. ožujka 1880. Iz Zagreba on je otišao Beč gdje se poklonio caru Franji Josipu, upoznao apostolskoga nuncija Jacobinija te konačno krenuo za Rim. Lav XIII. primio ga je u službenu audijenciju. Poslije povratka iz Rima Buconjić je bio instaliran za novoga apostolskog vikara u Hercegovini 25. travnja 1880., na blagdan sv. Marka. ${ }^{53}$

\section{Izbor i imenovanje fra Paškala Buconjića mostarsko-duvanj- skim biskupom}

Fra Paškal Buconjić nije dugo ostao apostolski vikar u Hercegovini. Nova država, Austro-Ugarska, donijela je ogromne promjene ne samo u državnoj administraciji nego i u preuređenju crkvenih struktura. Dok su vlade Austrije i Ugarske, preko zajedničkih ministarstava u Beču, ukoliko su se uspjele međusobno dogovoriti, mogle slobodno preuređivati novozaposjednute pokrajine $\mathrm{u}$ administrativnome, pravnome i gospodarskome pogledu, u duhu vlastitoga i međunarodnog prava i tradicije, u crkvenom pogledu nisu imale istu slobodu. Odnosi između Države i Crkve u Europi, počevši od Wormskoga konkordata ili ugovora iz 1122. godine ${ }^{54}$ bili su regulirani bilateralnim konkordatima, konvencijama ili ugovorima između Svete Stolice i Svetoga Rimskog Carstva Njemačke Nacije. Ovu praksu Zapadnoga Carstva preuzela su i druga samostalna europska kraljevstva, vojvodstva i kneževine. ${ }^{55}$ Habsburška Monarhija,

53 Buconjić kardinalu Siemeoniju, 15. 5. 1880. AP, SC Bosnia, vol. 17, fol. 150r-v; R. Glavaš, Biskup o. Paškal Buconjić, str. 9; P. VRankić, Religion und Politik, str. 509.

54 Wolfgang Dietrich Fritz, Quellen zum Wormser Konkordat. (Kleine Texte für Vorlesungen und Übungen, Band 177), Berlin, 1968.; Mathias Herweg, Wormser Konkordat 1122. Faksimile-Ausgabe. (Deutsche Geschichte in Dokumenten), Braunschweig, 2005.; Peter Classen, Das Wormser Konkordat in der deutschen Verfassungsgeschichte, u: J. FLECKENSTEIN (prir.), Investiturstreit und Reichsverfassung. (Vorträge und Forschungen, 17), Thorbecke, Sigmaringen, 1973., str. 411-460.

55 Poslije Svetoga Rimskog Carstva konkordate, konvencije ili državne ugovore sa Svetom Stolicom sklopile su tijekom stoljeća skoro sve europske zemlje: Aragon- 
poslije propasti Svetoga Rimskog Carstva, zadržala je tu staru tradiciju u svojim nasljednim zemljama, dok je u novoosvojene zemlje po potrebi uvela konkordatsku praksu. Odmah po zaposjednuću BiH započela je pregovore $s$ Ekumenskim patrijarhatom u Carigradu za reguliranje odnosa s Pravoslavnom Crkvom u BiH i konačno pregovore okrunila Konvencijom od 28. ožujka $1880 .{ }^{56}$ Austro-ugarska vlada započela je pregovore i s Turskom Carevinom glede reguliranja odnosa s muslimanskom zajednicom u BiH i uspješno ih završila 17. listopada $1882 .{ }^{57}$ Pregovori sa Svetom Stolicom za preuređenje odnosa u Katoličkoj crkvi u BiH, kako smo u uvodu spomenuli, završeni su u lipnju 1881. Po spomenutoj Konvenciji u Hercegovini je zadržana stara Trebinjska biskupija, a u Mostaru osnovana Mostarska biskupija s proširenim naslovom Mostarsko-duvanjska biskupija na mjesto već postojećega Apostolskog vikarijata u Hercegovini.

Ovim preuređenjem perspektive apostolskoga vikara Buconjića, da postane prvi mostarsko-duvanjski biskup, postale su veoma realne. $\mathrm{Za}$ razliku od njegova subrata u Bosni, vikara fra Paškala Vuičića, Buconjiću su vidno porasli izgledi da postane rezidencijalni biskup. Buconjić je svjesno i inteligentno radio na svojoj karijeri. On se još kao student u Ferrari, pod dojmom domoljubno orijentiranih hrvatskih časnika u službi Austrije, hrvatski i proaustrijski probudio i osvijestio. Prigodom tisućugodišnjice slavenskih apostola sv. Ćirila i Metoda, 1863. godine, održao je veoma zapažen govor u čast Svete braće i proširio svoje slavenske i ćirilo-metodske vidike. ${ }^{58}$ Buconjić se 1880 . godine, u svojoj ši-

ska 1208., Engleska 1213., Francuska 1268., Francusko Carstvo 1801., Austrijsko Carstvo 1855., Kneževina Crna Gora 1886., Kraljevina Srbija 1914., Kraljevina Italija 1929., Treće Njemačko Carstvo 1933., Kraljevina Jugoslavija, neratificirani konkordat iz 1935., SFR Jugoslavija, Protokol iz 1965., Republika Hrvatska, četiri ugovora od 1997.-1998., Bosna i Hercegovina, Temeljni ugovor iz 2006. Usp. ANGELO MerCATI (prir.), Raccolta di concordati su materie ecclesiastiche tra la Santa Sede e le autorità civili 1098-1914, I-II, Tipografia poliglotta vaticana, Città del Vaticano, 1954.; Erminio Lora (prir.), Enchiridion dei Concordati: due secoli di storia dei rapporti chiesa-stato, EDB, Bologna, 2003.; IgINo CARDInAle, Le SaintSiège et la diplomatie. Apreçu historique, juridique et pratique de la diplomatie pontificale, Desclée et Cie, Paris - Tournai - Rome - New York, 1962.; MichaEL F. Feldkampf, La diplomazia pontificia: da Silvestro I a Giovanni Paolo II. Un profilo, Jaca Book, Milano, 1998.

56 P. VRankić, Religion und Politik, str. 109-134.

57 K. und K. Gemeinsames Finanzministerium (prir.), Bericht über die Verwaltung von Bosnien und der Hercegovina 1906, str. 125; N. ŠEHIĆ, Autonomni pokret muslimana, str. 19-30.

58 Govor se posebno svidio prisutnom đakovačkom biskupu, Strossmayeru, koji ga je dao o svom trošku u Rimu tiskati. Usp. R. Glavaš, Biskup o. Paškal Buconjić, str. 9. 
rokogrudnijoj hrvatskoj viziji, mudro odlučio za biskupsko posvećenje u Zagrebu i time uspostavio izravne odnose s hrvatskim metropolitom, kardinalom Mihalovićem. Mogao je Buconjić mnogo lakše poći u susjednu Dalmaciju i dati se posvetiti od zadarskoga nadbiskupa Maupasa, splitskoga biskupa Kalođere ili susjednoga dubrovačkog biskupa Zaffrona. Svojom odlukom da organizira biskupsko posvećenje u Zagrebu, Buconjić je oslobodio Apostolski vikarijat i Katoličku crkvu u zapadnome dijelu Hercegovine iz geta, u koji su ih strpali prvo bosanski franjevci a kasnije, uz njihovu pomoć, i đakovački biskup Strossmayer. Kardinal Mihalović bio je pitan u ljeto 1880. od bečkoga nuncija Jacobinija o potrebi i opsegu preuređenja Katoličke crkve u BiH. Sigurno je kardinal vijećao o tome i s novoposvećenim biskupom Buconjićem u ožujku 1880. te stekao najpovoljnije dojmove o njemu. I nuncij Jacobini, koji će kasnije postati kardinal državni tajnik, upoznao je Buconjića u Beču za vrijeme njegova pohoda Caru u proljeće 1880 . Bez sumnje, i on je ostao impresioniran učenošću, duhovnošću i spretnošću novoga apostolskog vikara u Hercegovini. No, Buconjić je na Bečkom dvoru i u austro-ugarskoj vladi bio manje poznat po svojoj crkvenosti a više po svojim političkim nastupima i potezima. Tu je prije svega njegov otvoreni i javni nastup i pozdrav upućen caru Franji Josipu 24. travnja 1875. u Imotskom, prilikom Careva posjeta Dalmaciji. Tom prilikom on je podastro caru Franji Josipu spomenicu o žalosnom stanju katoličkoga puka u Hercegovini. ${ }^{59} \mathrm{Za}$ takav jedan čin trebalo je puno osobne hrabrosti, domoljublja i crkvenoljublja. Za ovaj čin, koji je u očima Osmanlija i domaćih muslimana bio viđen kao veleizdajnički akt, plaćala se najviša moguća kazna, gubljenje glave, kao što se upravo dogodilo za sličnu hrabrost bosanskom franjevcu, fra Lovri Karauli, u Žiroviću kod Livna 20. srpnja $1875 .{ }^{60}$ Buconjić predaje predstavnicima europskih sila, koji su trebali posredovati između ustanika i Osmanlija 1875. u Hercegovini, sljedeći spis: "Kratki pregled pritužaba", ${ }^{61}$ koji je isto tako bio primijećen od austrijsko-ugarske diplomacije. Ne smije se zaboraviti njegov odlučni nastup s vikarom Kraljevićem 1876. godine protiv crnogorskih pretenzija na Hercegovinu, što je uvelike pridonijelo kako Buconjićevu ugledu tako i ugledu Hrvata i katolika u Hercegovini. ${ }^{62}$ Poslije zaposjednuća BiH Buconjić je bio član sveopće bosansko-hercegovačke delegacije, koja se poklonila caru Franji Josipu u Budimpešti. Buconjić

59 Isti, str. 11-12.

60 Isti, str. 12.

61 Pascale Buconjić, Un cenno semplice sui gravami, causa principale insurrezione delle popolazioni cristiane in Erzegovina, Mostar, 1875.

62 R. Glavaš, Biskup o. Paškal Buconjić, str. 13-14. 
je bio sastavljač, uz neznatne preinake, pozdravne adrese hercegovačkih zastupnika 12. studenoga $1878 .^{63}$

Sve ove točke bile su veliki utezi na vagi kod Buconjićeva imenovanja za prvoga biskupa u Mostaru. Zajednički ministar financija, i odgovorni ministar za BiH, Josip Szlávy, predložio je apostolskoga vikara Buconjića za prvoga biskupa novoosnovane Mostarsko-duvanjske biskupije. Car je po Konvenciji od 8. lipnja 1881. imao isključivo pravo imenovati bosansko-hercegovačke biskupe, pravo koje je imao u svim biskupijama Austro-Ugarske Monarhije. Franjo Josip složio se s prijedlogom ministra Szlávya te je imenovao 9. listopada 1881. Buconjića za biskupa u Mostaru ${ }^{64}$ Carsko imenovanje bilo je proslijeđeno u Ministarstvo vanjskih poslova. Ministar Haymerle dao je odmah nalog veleposlanstvu u Rimu da isposluje službeno priznanje Svete Stolice. Budući da je i Sveta Stolica bila zadovoljna osobom i carskim imenovanjem, javio je kardinal Jacobini u Beč da je ovo imenovanje izvršeno na izričitu želju Svetoga Oca. ${ }^{65} \mathrm{U}$ tajnom konzistoriju od 18. studenoga 1881. proklamirao je Lav XIII. vikara Buconjića prvim rezidencijalnim biskupom u Mostaru i razriješio ga naslovnoga magydskog biskupa in partibus infidelium. ${ }^{66}$ Zemaljska vlada u Sarajevu nije skrivala svoje zadovoljstvo Buconjićevim imenovanjem za biskupa u Mostaru i nije se ni prevarila u svojim nadama i očekivanjima. Buconjić se potiho ali ustrajno pokazao kao stabilna osoba i veoma siguran oslonac u bosansko-hercegovačkom episkopatu za austro-ugarsku vjersku i nacionalnu politiku u $\mathrm{BiH}$.

\section{Imenovanje fra Paškala Buconjića trebinjsko-mrkanskim upraviteljem}

\subsection{Pokušaj oživljavanja Trebinjsko-mrkanske biskupije}

Trebinjska je biskupija strašno stradala za vrijeme Hercegovačkoga ustanka (1875.-1878.). Njezin teritorij bio je jedno od glavnih poprišta i vojnih sukoba između kršćanskih ustanika i turskih redovnih trupa, potpomognutih od domaćega muslimanskog stanovništva. Župe su bile opustošene, vjernici se razbježali, dok se većina svećenika bila sklonila u susjednu Dalmaciju. Poslije zaposjedanja po austro-ugarskim trupama

63 Isti, str. 15-16.

64 ASV, A. Cons. 1881. nr. 49; ABH Sarajevo, GFM Res. BH 15/1882.; P. VRankić, Religion und Politik, str. 511.

65 "Questa nomina è seguita dietro espresso desiderio di Sua Santità." ASV, AN Vienna, vol. 595, fol. 373r.

66 ASV, A. Cons. 1881., fol. 382v-383r. 
1878. godine porasla je nada u bolji i dostojniji život: puk se vraćao u razorena i popaljena sela, svećenici u porušene i opljačkane crkve i župne kuće. ${ }^{67} \mathrm{U}$ doba pregovora oko preuređenja crkvenoga stanja u $\mathrm{BiH}$ austrijski predsjedavajući ministar, grof Taafe, i zemaljski namjesnik u Zadru, general Rodić, nisu bili voljni da se Trebinjska biskupija izuzme ispod administracije dubrovačkoga biskupa. Tomu se usprotivio i dubrovački biskup Ivan Zaffron i njegov stolni kaptol. Sveti Zbor za širenje vjere u Rimu, provikar Lazarević, svećenici i puk Trebinjske biskupije tražili su vlastitoga biskupa. Toj njihovoj želji pridružio se kasnije i biskup Zaffron te je s provikarom Lazarevićem predlagao apostolskoga vikara u Egiptu, fra Alojzija Ivana Ćurčiju, dubrovačkoga franjevca, za trebinjskoga biskupa. ${ }^{68}$ No Zajednička vlada u Beču nije mogla udovoljiti kako vjersko-političkim tako financijsko-materijalnim željama svećenika i puka Trebinjske biskupije. Iz obzira prema pravoslavnim kršćanima, o čijoj se budućnosti već duže pregovaralo s ekumenskim patrijarhom u Carigradu, Beč nije mogao povećati broj biskupa i biskupija za katolike, koji su bili daleko malobrojniji od pravoslavnih u $\mathrm{BiH}$. Po Konvenciji od 8. lipnja 1881. ostala je Trebinjsko-mrkanska biskupija i dalje pod upravom dubrovačkoga biskupa dok se Sveta Stolica i Vlada $\mathrm{u}$ Beču ne dogovore posebnim ugovorom za njezino novo preuređenje. ${ }^{69}$ To je bila na početku mudra i logična odluka koja je proizlazila iz političkoga kontinuiteta ali i veoma često prolazna opcija do konačnoga rješenja, koje se 1881. godine nije dalo još naslutiti. Pet mjeseci poslije Konvencije, četiri mjeseca poslije proglašenja uspostave redovite hijerarhije u BiH, molio je provikar Lazarević i dalje Sveti Zbor u Rimu za imenovanje vlastitoga biskupa u Trebinju, vjerojatno ne znajući još uvijek što su Beč i Rim u Konvenciji potpisali, ne znajući isto tako da Sveti Zbor za širenje vjere nije imao više nikakvih ovlasti za imenovanje biskupa u Trebinju i u cijeloj BiH. ${ }^{70}$ Provikar Lazarević i ostalo svećen-

67 Vrlo dobar prikaz teškoga stanja u Trebinjskoj biskupiji prije i poslije zaposjedanja donosi Ivica Puljić. Usp. Ivica Puljić, "Trebinjska biskupija u XIX stoljeću", u: Petar Babić - Mato Zovkić (prir.), Katolička Crkva u Bosni i Hercegovini u XIX i XX stoljeću, (Studia Vrhbosnensia - 1), Vrhbosanska visoka teološka škola, Sarajevo, 1986., str. 91-119, posebno str. 115-119.

68 Biskup Zaffron kardinalu Simeoniju, 18. 10. 1879., AP, SC Bosnia, vol. 17, fol. 32r33v; don Lazar Lazarević Simeoniju, 2. 12. 1879.; Isto, fol. 26r-27r; P. VRANKIĆ, Religion und Politik, str. 522.

69 Vidi gore bilj. 14. A. Mercati, Raccolta di concordati, str. 1014; P. VRAnkić, Religion und Politik, str. 523.

70 PVA Stolac, Koncept molbe provikara Lazarevića Svetom Zboru za širenje vjere od 6. 10. 1881. Usp. I. PuljIĆ, "Trebinjska biskupija u XIX stoljeću", str. 119. 
stvo Trebinjsko-mrkanske biskupije, kao dobri i vjerni pitomci Urbanova zavoda u Rimu, teško su se snalazili u ovim prijelomnim vremenima, nisu umno i voljno mogli ili htjeli usvojiti novonastalo crkveno-pravno i državno-pravno stanje Katoličke crkve u $\mathrm{BiH}$, koje je bilo zasnovano na Konvenciji i na buli Ex hac augusta iz 1881. godine.

Zaposjedanje i novo preuređenje crkvenih prilika u BiH donijeli su vidnih plodova na području Trebinjske biskupije: počele su se graditi nove crkve i nove župne kuće te obnavljati stare i porušene, podizati nove škole. Broj vjernika rastao je ponovo, novopridošli katolici iz Monarhije uključivali su se u život područne Crkve. I osim svih ovih vidnih uspjeha širilo se nezadovoljstvo među svećenstvom i pukom u biskupiji. Uz razne materijalne poteškoće, svećenici i puk nisu mogli razumjeti nehaj, nedovoljnu pomoć, ponekad i prijetnje novih lokalnih vlasti katoličkom stanovništvu, koje je jedino u odlučnom trenutku bilo stalo na stranu Monarhije. Osobito im je smetalo, uza sve njihove potrebe i nevolje, mlako i neodlučno držanje dubrovačkoga biskupa i apostolskoga upravitelja Mate Vodopića (1882.-1894.), biskupa-pjesnika, pisca i sanjara, te ponajviše, trajno i sistematsko miješanje biskupa Buconjića u jurisdikciju Trebinjske biskupije i u jurisdikciju provikara Lazarevića, svojatajući za sebe i za Mostarsku biskupiju sjeverne i sjeveroistočne dijelove biskupije. ${ }^{71}$ Opis novonastaloga nezadovoljstva susrećemo najbolje u pismu provikara Lazarevića od 11. lipnja 1887. pročelniku Svetoga Zbora za širenje vjere, kardinalu Simeoniju, gdje ga usrdno moli da uzme u zaštitu prava i granice Trebinjske biskupije i da ustane protiv zapostavljanja i proganjanja katolika od lokalnih vlasti. Provikar Lazarević vidio je jedino pravo rješenje u oživljavanju biskupije kroz imenovanje vlastitoga biskupa $\mathrm{u}$ Trebinju. ${ }^{72}$ Osim ovoga pisma u Rim poslao je provikar Lazarević u ljeto iste, 1887., godine opširnu predstavku i na Zemaljsku vladu u Sarajevo, gdje je pokušao upozoriti odgovorne na nepravilnosti i ingerenciju biskupa Buconjića te na opću zapostavljenost katolika u Trebinjskoj biskupiji. ${ }^{73}$

71 Ovdje se služimo i oslanjamo samo na dostupne izvore, koji se zbog svoje relevantnosti nalaze u spomenutim arhivima i koji se odnose na napore za oživljavanje Trebinjske biskupije s vlastitim biskupom ili upućuju na njezino podvrgavanje pod jurisdikciju mostarsko-duvanjskoga biskupa.

72 Lazarević Simeoniju, 11. 6. 1887. AP, SC Bosnia, vol. 17, fol. 593r-595v; P. VRANkić, Religion und Politik, str. 530. Ovom pismu od 11. lipnja 1888. moralo je prethoditi još jedno ranije pismo na koje se pozivaju kardinali Simeoni i Rampolla, kojega nisam mogao naći u Arhivu Propagande ni u Tajnom vatikanskom arhivu.

73 PVA Stolac, 14. 8. 1887., bez broja. Ovaj sam podatak dobio 1989. godine od tadašnjega župnika i dekana u Stocu, don Mate Puljića, te mu ovom prilikom najsrdačnije zahvaljujem. Usp. I. PuljIĆ, "Trebinjska biskupija u XIX stoljeću", str. 119. 
Predstavka nije našla nikakva pozitivnog odjeka u političkom Sarajevu. ${ }^{74}$ Isto tako Lazarević je upozorio i biskupa-upravitelja Vodopića na njegove dužnosti, no, ni on nije pokazivao većega interesa za povjereno stado u Trebinjskoj biskupiji. ${ }^{75} \mathrm{U}$ cijeloj ovoj napetosti imao je jedino Sveti Zbor za širenje vjere u Rimu još neko razumijevanje za potrebe Trebinjske biskupije, klera i puka, no nije bio u mogućnosti poduzeti nešto konkretnije u novonastaloj političko-pravnoj konstelaciji, tj. bez suglasnosti i materijalne pomoći austro-ugarske vlade. Stoga se obraća pročelnik Simeoni kardinalu državnom tajniku, Rampolli, za pomoć oko oživljavanja Trebinjske biskupije. Kardinal Rampolla izvješćuje papu Lava XIII., koji opet na svoj način izražava zabrinutost za loše stanje katolika u Trebinjskoj biskupiji te naređuje kardinalu Rampolli da otvori nove pregovore s austro-ugarskom vladom u Beču. Kardinal Rampolla daje nalog nunciju u Beču da započne pregovore. ${ }^{76}$ Luigi Galimberti, tadašnji nuncij u Beču, izlaže cijelu problematiku austro-ugarskom ministru vanjskih poslova, grofu Kálnokyju, i predaje mu osobno pismo kardinala Rampolle. ${ }^{77}$ Svi sljedeći koraci i pregovori odvijali su se u duhu ritualnoga birokratskog procesa unutar austro-ugarskih zajedničkih ministarstava, Ministarstva vanjskih poslova i Ministarstva financija. Ministar Kálnoky obavijestio je baruna Kállaya, zajedničkoga ministra financija, komu je bila podvrgnuta uprava $\mathrm{BiH}$, o željama Svete Stolice. Istovremeno odjelni pročelnik u Ministarstvu vanjskih poslova, barun Pasetti, odgovora preko nuncijature, 11. lipnja 1888. Svetoj Stolici: budući da je pitanje osnivanja biskupske stolice u Trebinju veoma važno i kompleksno, potrebno je unaprijed sakupiti sve podatke koji mogu poslužiti za potpune informacije. ${ }^{78} \mathrm{Mini}$ star Kállay daje nalog Zemaljskoj vladi u Sarajevu da provjeri jesu li točni prigovori i optužbe provikara Lazarevića, glede postupka lokalnih vlasti i ingerencije biskupa Buconjića.

74 Predstavku nisam našao u Arhivu BiH u Sarajevu. No, pozivanje na nju nalazi se u dokumentima istoga arhiva.

75 Tadašnji tajnik Dubrovačke biskupije, don Vlade Puce, saopćio mi je 1989. godine da nije mogao naći ovo pismo u Arhivu Dubrovačke biskupije.

76 Rampolla Galimbertiju, 29. 5. 1888. ASV, AN Vienna, vol. 640, fol. 2r-3r; P. VRANKIć, Religion und Politik, str. 530.

77 Galimberti Rampolli, 13. 6 1888. ASV, AN Vienna, vol. 640, fol. 6r-v; P. Vrankić, Religion und Politik, str. 530-531.

78 "La question de créer un siège épiscopal à Trebinje étant à la fois très importante et complexe, il est indispensable de réunir d'abord tous les éléments pouvant servir à compléter les informations." Pasetti nunciju Galimberttiju, 11. 6. 1888. ASV, AN Vienna, vol. 640, fol. 5r-v. 
U ovoj napetoj atmosferi obratiše se 5. rujna 1888. svi svećenici Trebinjske biskupije, njih sedam, nunciju Galimbertiju s opširnim podneskom i ponovo zatražiše imenovanje vlastitoga biskupa za njihovu biskupiju, poštivanje biskupijskih granica od biskupa Buconjića, kako ih je definirao Lav XIII. u buli Ex hac augusta te ga zamoliše da podrži njihove pravedne zahtjeve u Beču i u Rimu. ${ }^{79}$ Poslije svih ovih intervenata, predstavaka, preporuka, pozitivnih i negativnih mišljenja pripremila je Zemaljska vlada u Sarajevu i Ministarstvo financija u Beču svoje konačno mišljenje, čiji je mjerodavni autor bio ministar Kállay. Pročelnik Pasetti uručuje nunciju Galimbertiju u ime ministra vanjskih poslova 17. lipnja 1889., godinu dana poslije zamolbe Svete Stolice, službeni stav Beča, dogotovljen u Ministarstvu financija. ${ }^{80}$ Uručeni akt veliki je slalom istine, poluistine i vještoga manipuliranja poviješću Katoličke crkve u Hercegovini i u Trebinjskoj biskupiji, koji može ući u svaki bolji priručnik diplomatske nedorečenosti: za nedovoljno informirani Rim, nemoćni i neupućeni kler Trebinjske biskupije i za nezainteresiranoga biskupa Vodopića. Prema mišljenju službenoga Beča na području Hercegovine postojala je prije doseljenja Slavena (Hrvata) samo jedna biskupija, Martaritana, koja se djelomično nalazila na području Hercegovine. ${ }^{81}$ Tako, prema službenome Beču, nema dokaza da je Trebinje bilo nekad dio biskupije Dubrovnik i da je Hercegovina bila podijeljena u više biskupijskih jedinica. ${ }^{82}$ Stoga je, za Ministarstvo u Beču, veza Trebinja s Dubrovnikom nebitna. Kállay razumije i podupire želju Svete Stolice da izuzme Trebinjsku biskupiju ispod jurisdikcije dubrovačkoga biskupa i da osnuje jednu samostalnu biskupiju. On se slaže sa željom Svete Stolice da bi valjalo jurisdikciju dubrovačkoga biskupa nad Trebinjem prekinuti i predlaže Trebinjsku biskupiju staviti pod jurisdikciju mostarskoga biskupa, budući da bi se tada obje biskupije našle u istoj političkoj administrativnoj jedinici BiH i da je Mostar politički i administrativni

79 Svećenici Trebinjske biskupije nunciju Galimbertiju, 5. rujna 1888. ASV, AN Vienna, vol. 640, fol. 9r-16r. Kopiju ove predstavke poslali su i biskupu upravitelju Vodopiću u Dubrovnik. P. Vrankić, Religion und Politik, str. 531.

80 Pasetti nunciju Galimbertiju, 17. 1. 1889. ASV, AN Vienna, vol. 640, fol. 21r-30v; P. VRAnkić, Religion und Politik, str. 531.

81 "que dans cette époque il existait, á coté d'une diocèse pour le territoire de Raguse (Epitaurus) un évêché séparé, nominé Martaritana correspondant á peu prés á l'Herzégovine de nos jours." Isto, ASV, AN Vienna, vol. 640, fol. 21v. Da bi Beč mogao potvrditi svoje teze, služi se zastarjelom bibliografijom, ponajviše djelom splitskoga svećenika Carrare. Usp. Francesco Carrara, Chiesa di Spalato, un tempo Salonitana, Spalato, 1844., str. 32.

82 Pasetti nunciju Galimbertiju, 17. 1. 1889. ASV, AN Vienna, vol. 640, fol. 22r; P. VRAnkić, Religion und Politik, str. 531. 
centar i za vjernike Trebinjske biskupije, dok Trebinje to nije ni u kojem slučaju. Osnivanje novoga biskupskog sjedišta u Trebinju dovelo bi do borbe s prirodnim poteškoćama koje bi od samoga početka paralizirale akcije biskupske stolice. ${ }^{83}$ Stoga, zaključuje Kállay hladno i činovnički, da bi se izbjegle sve spomenute i nastale poteškoće u pastvi i školama treba spojiti distrikt, dosad pod upravom dubrovačkoga biskupa, Trebinjsku biskupiju, s Mostarskom biskupijom. ${ }^{84}$

Nuncij Galimberti proslijedi stav službenoga Beča u Rim. Kardinali, Simeoni i Rampolla, nakon internih konzultacija, brzo su uvidjeli da Beč ne želi i ne može iz obzira prema pravoslavnima osnovati i dotirati novo biskupsko sjedište u Hercegovini te počeše i sami argumentirati, da je bolje da u tom slučaju administracija Trebinjske biskupije prijeđe u ruke mostarskoga biskupa. Dalje, obojica kardinala, u svome kurijalnom i talijanskom (ne)znanju, navode da je dobro da uprava Trebinjske biskupije prijeđe u ruke mostarskoga biskupa, budući da dotični biskup govori jezik toga puka. U talijanskoj iredentističkoj viziji Dalmacije toga vremena, na žalost, mislilo se, kako na Kuriji u Rimu tako i u dnevnoj talijanskoj politici, da se u Dubrovniku i u Dalmaciji govorilo samo talijanski. ${ }^{85}$ Promjenu rimskoga stava saopćio je nuncij Galimberti odjelnom pročelniku Pasettiju 23. rujna 1889. ${ }^{86}$ Ipak su kardinali Simeoni i Rampolla vidjeli u ovoj odluci carske vlade pozitivan znak, ako Trebinjska biskupija i dalje bude sačuvana, da ne treba gubiti nadu da će se u daljnjoj budućnosti moći obnoviti s vlastitim biskupom. ${ }^{87}$

83 "Installé á Trebinje, le nouveau siège épiscopal aurait á lutter, dés le début, contre des difficultés naturelles qui paralyseraient tout son action." Isto, ASV, AN Vienna, vol. 640, fol. 27r; P. VRAnkić, Religion und Politik, str. 532.

84 "Toutes ces considérations conduisent á la conclusion que, pour faire disparaitre les inconvénients actuels, et pour préparer une situation dans laquelle le culte catholique puisse prendre en Herzégovine l'essor mérité et désiré par le Gouvernement, il faudrait réunir les districts jusqu'ici subordonnés á Raguse avec l'évêché de Mostar." Isto, ASV, AN Vienna, vol. 640, fol. 30r; P. VRankić, Religion und Politik, str. 532.

85 "Siffatto temperamento, come la S.V. vedrà di leggere, procura il vantaggio ai cattolici di Trebinje di avere il Pastore che parla il loro idioma." Rampolla nunciju Galimbertiju, 18. 9. 1889. ASV, AN Vienna, vol. 640, fol. 31v; P. VRankić, Religion und Politik, str. 532.

86 Galimberti Pasettiju, 23. 9. 1889. ASV, AN Vienna, vol. 640, fol. 33r-v; P. VRaNKIĆ, Religion und Politik, str. 532.

87 "È poi manifesto che conservandosi la diocesi, non si perde la speranza di vederla in un avvenire più o meno remoto ricostituita con un Vescovo proprio." Rampolla nunciju Galimbertiju, 18. 9. 1889. ASV, AN Vienna, vol. 640, fol. 31v; P. VRANKIĆ, Religion und Politik, str. 532. 
Beč se pokazao prezahvalan (avec la plus grande reconnaissance) odlukom Rima te je zaželio da jurisdikcija mostarskoga biskupa nad Trebinjskom biskupijom, premda privremenoga karaktera, ima redovitu formu. Još je jednu važnu želju izrazio Beč i zamolio da mostarski biskup može imenovati hercegovačke franjevce na župe Trebinjske biskupije. Beču je bilo stalo da hercegovački franjevci, koji se školuju u duhu Monarhije, dođu i na župe Trebinjske biskupije. Dijecezanski kler, koji se školovao u Urbanovu zavodu Svetoga Zbora za širenje vjere u Rimu, daleko od utjecaja bečke vlade, nije uživao povjerenje ministra Kállaya, koji je od 1882. instalirao snažnu filofranjevačku crkvenu politiku u $\mathrm{BiH}^{88}$ Još jednu povijesnu netočnost otkriva ovaj dopis i dovodi u zabludu, kada govori o dijecezanskome kleru u Trebinjskoj biskupiji, kao da ga nema ili da ne postoji kao domaći kler. ${ }^{89}$ Sveta Stolica, sa svoje strane, nije u potpunosti prihvatila dvije zadnje želje ministra Kállaya nego je odgovorila da ne vidi poteškoću prepustiti upravu Trebinjske biskupije biskupu u Mostaru u obliku iste jurisdikcije koju je imao dubrovački biskup. Nakon preuzimanja administracije od dubrovačkoga biskupa može mostarski biskup, ukoliko mu to olakšava pastoralnu službu, podnijeti Svetoj Stolici posebne zamolbe za dodatne povlastice. ${ }^{90}$

\subsection{Buconjić apostolski upravitelj trebinjsko-mrkanski}

Poslije trogodišnje napetosti i dvogodišnjega pregovaranja konačno je bila uglavljena definitivna predaja uprave Trebinjske biskupije iz ruku dubrovačkoga biskupa u ruke biskupa u Mostaru. Ministar Kállay i ministar Kálnoky bili su konačno zadovoljni, premda im Sveta Stolica nije

88 "Ensuite, nous pensons qu'il serait très désirable que les paroisses du diocèse de Trebinje ne fussent pas fermée aux ecclésiastiques de l'ordre de St. François de l'Herzégovine et que l'évêque de Mostar fût autorisé á choisir les curés aussi dans cet ordre aussi longtemps du moins que des prêtres séculiers indigène de cette province ne pourront pas être employés." Pročelnik Pasetti nunciju Galimbertiju, 8. 6. 1890. ASV, AN Vienna, vol. 640, fol. 38r; P. VRankić, Religion und Politik, str. 532-533.

89 Isto. Povijesni promatrač stječe dojam da ministar Kállay podupire interese redovničkoga klera - franjevaca, kako u Bosni tako sada i u Hercegovini, na štetu dijecezanskoga klera.

90 "Ella poi nel comunicare al Sig. Ministro la surriferita risposta, gli farà intendere, che qualora quel Prelato, dopo avere assunta l'amministrazione della Diocesi, trovasse necessaria al disimpegno del suo ministero pastorale qualche altra facoltà, potrà rivolgersi alla Santa Sede come suole praticarsi in simili circostanze." Rampolla Galimbertiju, 19. 2. 1890. ASV, AN Vienna, vol. 640, fol. 42r-v; P. VRANKIĆ, Religion und Politik, str. 533. 
izravno ispunila dvije zadnje želje. ${ }^{91}$ Sveti Zbor za širenje vjere naredio je svojim dekretom od 16. lipnja 1890. da administracija Trebinjske biskupije prijeđe u ruke mostarskoga biskupa. ${ }^{92}$ Papa Lav XIII. sankcionirao je odluku Svetoga Zbora za širenje vjere breveom od 8. srpnja 1890. gdje čitamo: "Stoga Našom apostolskom vlašću, snagom ovoga Pisma, upravu Crkava Trebinjske i Mrkanske trajno sjedinjenih, koju je do sada vodio dubrovački biskup, prenosimo na mostarskoga biskupa pro tempore bilo u duhovnim bilo u vremenitim stvarima ad beneplacitum Nostrum, tj. do drukčije odluke."93

Papinskim breveom biskup Buconjić postao je apostolski upravitelj Trebinjsko-mrkanske biskupije i time svladao zadnju prepreku u proširenju svoje biskupske jurisdikcije nad cijelom Hercegovinom. Premda Buconjić nije poštivao jurisdikciju dubrovačkoga biskupa i njegova provikara u Trebinjskoj biskupiji, nije jasno koliko je on osobno i izravno sudjelovao u ovome ekspanzionističkom crkvenom pothvatu, odnosno koliko je sam surađivao i davao podršku Zemaljskoj vladi u Sarajevu i njezinim planovima za njegovu promociju. $S$ druge strane, treba isto tako otvoreno priznati, da prosvjedi i napori dijecezanskoga klera Trebinjsko-mrkanske biskupije protiv Buconjićeve ingerencije, zlouporabe njegove vlastite jurisdikcije, nepoštivanje dijecezanskih granica te nezadovoljstvo toga svećenstva s upravom dubrovačkoga biskupa Vodopića i njegovim nehajem za povjereno mu stado, nije postiglo željeni cilj: oživljavanje Trebinjske biskupije i imenovanje vlastitoga biskupa. Bez vrlo uplivnih saveznika u Mostaru, Sarajevu, Beču i Rimu nije mogao proći u Beču tako važan projekt svećenstva Trebinjske biskupije. U trenutačno dostupnom arhivskom materijalu, samo primjera radi, ne pojavljuje se ime vrhbosanskoga metropolite, nadbiskupa Stadlera, kao zagovornika, koji je mogao, bez sumnje, preuzeti veoma odgovornu ulogu u ovome sporu, između načelne financijske štednje Zemaljske vlade u Sarajevu i oprav-

91 Pasetti nunciju Galimbertiju, 5. 4. 1890. ASV, AN Vienna, vol. 640, fol. 44r-45r; P. VRAnkić, Religion und Politik, str. 533.

92 Vrlo je zanimljivo da je ovaj dekret izdao Sveti Zbor za širenje vjere a ne Zbor za izvanredne crkvene poslove u čiju je jurisdikciju, po Konvenciji iz godine 1881., došla Crkva u BiH. Ovo se može jedino objasniti dugim povijesnim iskustvom Svetoga Zbora za širenje vjere po pitanjima Crkve u BiH i trenutačno nedovoljnom upućenošću Svetoga Zbora za izvanredne crkvene poslove, posebno njegova još svježeg tajnika Domenika Ferrate, u problematiku Katoličke crkve u BiH.

93 Leonis XIII Pontificis Maximi Acta, vol. X., Romae, 1891., str. 182. 
danih želja svećenstva Trebinjsko-mrkanske biskupije. ${ }^{94}$ Dogodilo se po onoj rimskoj poslovici: Dok se dvojica svađaju, treći se veseli. ${ }^{95}$

Zemaljska vlada u Sarajevu i Ministarstvo financija u Beču podupirali su, od početka, kako svoje tako i Buconjićeve planove i ciljeve, dok konačno nisu bili okrunjeni punim uspjehom papinom odlukom iz 1890. godine. Time se biskup Buconjić pokazao još jednom kao čovjek velikoga povjerenja austro-ugarske politike kako u Mostarsko-duvanjskoj, tako i u Trebinjsko-mrkanskoj biskupiji i time u cijeloj Crkvi Hercegovine.

\section{Završne misli}

U svome tridesetogodišnjem biskupskom djelovanju biskup Buconjić istaknuo se kao veliki hrvatski rodoljub. No prvenstveno on biva spominjan kao vrlo zaslužni sin Hercegovačke franjevačke kustodije i novoosnovane provincije, veliki prijatelj hercegovačkih franjevaca, vjerni promicatelj njihovih potreba i interesa, kako u Mostaru tako i po cijeloj Hercegovini. Neke od tih njegovih zasluga najbolje nabraja 1910. godine njegov tajnik i biograf, fra Radoslav Glavaš, prigodom tridesetogodišnjice biskupske službe, koje ovdje citiramo: "Franjevačka mu hercegovačka provincija mora da vječno harna ostane, ne samo radi mnogih usluga učinjenih joj svakom prilikom, nego naročito i radi toga što je glavni grad Mostar očuvao za franjevce, te su mogli da njegovom obilnom pripomoću podignu krasan samostan i prostrano bogoslovno sjemenište. Tik same crkve poklonio je lijep komad najboljeg zemljišta, nekoliko vinograda u okolici i prostranu sjenokošu u Blatu za uzdržavanje bogoslova u Mostaru. A kako se plelo, da nije bilo biskupova upliva, zagovora i zaštite uz obilnu pripomoć ne bi si franjevci nikad tako ugodno prebivalište zasnovali bili u kamenitom Mostaru. Radilo se naime, sa stanovite i mjerodavne strane, da se tadanja župska crkva i stan oduzme franjevcima, pa da crkva služi za katedralku, a župski stan za biskupsku residenciju, a franjevci da se zavuku postrance u Vukodô, u staru i trošnu biskupsku residenciju, da odatle motre šaroliki Mostar i broje

94 U arhivima Sarajeva, Beča i Rima nisam naišao na tragove Stadlerova zauzimanja za opravdane potrebe klera Trebinjske biskupije u ovoj problematici. Možda je vikar Lazarević mislio, u duhu misijskoga prava, da se sva pitanja u Trebinjskoj biskupiji mogu riješiti preko Svetoga Zbora za širenje vjere.

95 Duobus litigantibus tertius gaudet. Joseph EISElEIn, Die Sprichwörter und Sinnreden des deutschen Volkes in alter und neuer Zeit, Literarischer Verlag, Donaueschingen, 1838., str. 267. 
zvijezde po nebesima gledajući poviš sebe, kako vrhu njihovih glava viju suri orli lješinari!"96

Prelijepa slika idealne harmonije između biskupa i hercegovačkih franjevaca i istovremeno manje lijepa slika neskromnog tajnika i hercegovačkoga franjevca Glavaša! Biskup je uistinu ostao u Vukodolu sve do 24. ožujka 1909. i vijanje orlova "lješinara" iznad njegove glave nisu ga spriječili činiti dobro za svoju subraću, hercegovačke franjevce, za njihov pomladak, samostane, crkve i za hrvatsku stvar. Istovremeno Glavaš ne spominje i ne daje nigdje naslutiti neku Buconjićevu zaslugu za svjetovno svećenstvo (dijecezanski kler) u Mostarskoj i u Trebinjskoj biskupiji. Tako, kroz pero Buconjićeva biografa, dobiva se, između redaka, dobra slika neispunjene biskupske dužnosti i nepostojeće harmonije između biskupa i njegova postojećeg i nepostojećeg biskupijskog svećenstva, koje mu je bilo povjereno!

Laudator Glavaš te mnogi drugi poslije njega ne spominju ili ne naslućuju novu dimenziju franjevaštva u Hercegovini, koja je bila instalirana Buconjićevom zaslugom. Buconjić je bio, bez sumnje, istovremeno vrlo spretan, sposoban i poslovan kako homo religiosus tako i homo politicus. On se suvereno oslobađao od folklorne slike i nostalgičnog pojma franjevca kao bosanskog ujaka te je obilato pomagao, postupno stvarao i uobličavao novi model Franjina sljedbenika u Hercegovini: domoljubno, hercegovački i hrvatski orijentiranoga franjevca. Taj novi model, za razliku od njegova prethodnika i suvremenika u Bosni, raskidao je uspješnije s duhom podčinjenosti, koji je proizlazio iz Milodraške Ahdname is duhom nostalgije za Osmanskim Carstvom i njegovim padišahom u Stambolu. Fra Paškal Buconjić je njegovao, jačao i proširivao taj novi model franjevaštva, potpomognut novim i zavidnim povlasticama katolicizmu naklonjene Habsburške Monarhije. No, i on je istovremeno svjesno i uporno nastojao zadržati stari duh privilegirane franjevačke isključivosti, utemeljene na stoljetnim povlasticama Svete Stolice (privilegia et iura specialia franciscana) i na povlasticama padišaha iz Stambola. Time su bili udareni temelji, zahvaljujući poglavito nepostojećoj konkurenciji i političkoj vještini biskupa Buconjića, za jedno novo, snažnije i prodornije, isključivošću nadahnuto hercegovačko franjevaštvo, koje mu je, gle kontradikcije, Konvencijom iz 1881. godine, omogućila jedna pravna, u bosansko-hercegovačkoj franjevačkoj historiografiji veoma dugo ocrnjivana država, Austro-Ugarska Monarhija. Je li to kontradikcija povijesne, povjesničarske, političke ili politikantske naravi,

96 R. Glavaš, Biskup o. Paškal Buconjić, str. 19-20; M. Perić, "Život i rad mostarsko-duvanjskih i trebinjsko-mrkanskih biskupa", str. 279. 
vizije i volje, ili prateća pojava hercegovačko-bosanskoga crkvenog podneblja, dalo bi se nadugo govoriti i trebalo bi ozbiljno raspravljati?!

Zanimljivo je ovdje još spomenuti puninu biskupske vlasti (jurisdictionis) i časti (honoris) u Hercegovini, koju je u zadnjih 130 godina jedino biskup Buconjić mogao uživati nesmetano u svoj svojoj punini i sve do svoje smrti. Tu puninu biskupske vlasti i časti u Hercegovini dobivali su i dobivaju još uvijek de iure svi njegovi nasljednici. No, ta je punina postupno i de facto počela blijedjeti već 1912 . godine, izborom i imenovanjem biskupa fra Alojzija Mišića, bosanskoga franjevca i bosanskog Hrvata, rodom iz Bosanske Gradiške, "stranca" među hercegovačkim franjevcima, kao što je i Josip Stadler, Brođanin, Slavonac, Zagrepčanin i Hrvat, bio "stranac" u Bosni za bosanske franjevce 1881. godine. Mišić nije bio persona grata (poželjna osoba) hercegovačkoga franjevačkog ozračja. Time je, danas promatrano, nostalgična harmonija biskupstva i franjevačkoga svećenstva u Hercegovini iz Buconjićeva doba, koja je bila potpuno u hercegovačko-franjevačkoj ruci, postajala sve nedokučivija u zadnjih stotinu godina, kako za mostarsko-duvanjske biskupe tako i za hercegovačke franjevce i hercegovačko biskupijsko svećenstvo. ${ }^{97}$

97 O tome ćemo možda moći više saznati u sljedećem prilogu. 


\section{Election and nomination of bishops in Herzegovina during the Austro-Hungarian rule (1878-1918), the case of Bishop Pascal Buconjic}

\section{Summary}

Election and nomination of bishops in the Catholic Church has always been a very complex and politically sensitive issue. With the occupation of Bosnia-Herzegovina in 1878 and the introduction of new legal, economic and administrative regulations, Austria-Hungary established new relations between the state and religious communities in Bosnia-Herzegovina. The Convention with the Ecumenical Patriarch of Constantinople of 28 March 1880 regulated the relations with the Orthodox Church in Bosnia-Herzegovina. After two years of very intensive negotiations between Vienna and the Holy See a similar solution was reached for the Catholic Church in Bosnia-Herzegovina. On 8 June 1881, the Convention between the Holy See and Austria-Hungary was signed in Rome, a document regulating the state-church relations in the Catholic Church in Bosnia-Herzegovina. In two other similar treaties, Austria-Hungary regulated the relations of the state with the Muslim and Jewish communities in Bosnia-Herzegovina. The Conventions between Austria-Hungary and the supreme representatives of religious communities in Bosnia-Herzegovina, as well as the contracts with other religious communities in different countries of the Monarchy, presented a kind of international agreement of political, legal and religious character and were an important feature of the legacy of the Austro-Hungarian Monarchy.

The Convention between the Holy See and Austria-Hungary brought along many political and canonical changes in comparison to four-century long Ottoman occupation and strong Islamic oppression symbolized in the Ahd-nama of Milodraz from 1463 as well as the rule of missionary canonical law, which was in force in Bosnia-Herzegovina until 1878 or 1881. The privilege of appointing Catholic bishops obviously deserved a special place in the Convention. The privilege of election and nomination of bishops in Bosnia-Herzegovina, according to the spirit of the Convention of 8 June 1881, was courtesy of Pope Leo XIII to "His Majesty" Francis Joseph, Emperor of Austria and King of Croatia-Hungary: Il Santo Padre.... concede alla stessa Maestà Sua il privilegio di nomina dell'Arcivescovo e dei Vescovi nella Bosnia e nell'Erzegovina. 
This short paper presents the concrete rule of state law and canonical law in the process of the election and appointment of the first bishop in Herzegovina, Pascal Buconjic OFM. In his triple function of an Apostolic Vicar in Herzegovina, a Bishop of Mostar-Duvno and finally an Apostolic Administrator of Trebinje-Mrkan, which he held successively, the state-church character of the reception and the realization of the Convention in Herzegovina were most clearly manifested. Buconjic, pleno sensu, a church man and a monk, thanks to his reputation and skill, enjoyed the position of trust with the State Government (Landesregierung) in Sarajevo, the Common Ministry of Finance in Vienna and the Emperor himself. Consequently, Buconjic as a bishop realized almost all his plans with the State, and the Austro-Hungarian Monarchy considered him as an excellent partner to promote its ecclesiastic and state plans with the Catholic Church in Herzegovina.

The author does not discuss, on purpose, the human, spiritual, religious, sacerdotal, pastoral and Episcopal characteristics of Bishop Pascal Buconjic, especially not his relation to the diocesan clergy and is happy to leave this task to other observers and investigators. He focuses on the interesting and successful profile of a Herzegovinian Franciscan Buconjic, which very quickly sets him apart from the nostalgic times of Franciscan exclusivism, based on privileges of the Ahd-nama of Milodraz but maintains all privileges of the Holy See (monumenta, privilegia et iura specialia franciscana) and other privileges of the Padişah in Istanbul that laid the foundations for a new and stronger exclusivism of future Franciscanism in Herzegovina. It is a contradiction that the Convention between Holy See and Austria-Hungary, which had so greatly promoted the Franciscanism in Bosnia and Herzegovina, was so strongly denigrated by Franciscan historiography in this country.

Keywords: Herzegovina, Bishop Pascal Buconjic, Apostolic Vicariate in Herzegovina, the Diocese of Mostar-Duvno, the Diocese of Trebinje-Mrkan, the Convention between the Holy See and Austria-Hungary, the Apostolic Bull "Ex hac augusta" of Leo XIII. 